\title{
Biochar-Added Cementitious Materials-A Review on Mechanical, Thermal, and Environmental Properties
}

\author{
Rhoda Afriyie Mensah ${ }^{1,+}$, Vigneshwaran Shanmugam ${ }^{2,+} \oplus$, Sreenivasan Narayanan ${ }^{3}$, \\ Seyed Mohammad Javad Razavi ${ }^{4, *(D)}$, Adrian Ulfberg ${ }^{1}$, Thomas Blanksvärd ${ }^{5}$, Faez Sayahi ${ }^{6}$, Peter Simonsson ${ }^{7}$, \\ Benjamin Reinke ${ }^{8}$, Michael Försth ${ }^{1}{ }^{1}$, Gabriel Sas ${ }^{1, *}{ }^{\circ}$, Daria Sas ${ }^{9}$ and Oisik Das ${ }^{1, *}$
}

1 Structural and Fire Engineering Division, Department of Civil, Environmental and Natural Resources Engineering, Luleå University of Technology, 97187 Luleå, Sweden; ramensah23@gmail.com (R.A.M.); adrian.ulfberg@ltu.se (A.U.); michael.forsth@ltu.se (M.F.)

2 Department of Mechanical Engineering, Saveetha School of Engineering, Saveetha Institute of Medical and Technical Sciences, Chennai 602105, Tamil Nadu, India; s.vigneshwaren@gmail.com

3 Department of Mechanical Engineering, Adishankara Institute of Engineering and Technology, Kalady Kerala 683574, India; sreenivasan.me@adishankara.ac.in

4 Department of Mechanical and Industrial Engineering, Norwegian University of Science and Technology (NTNU), 7491 Trondheim, Norway

5 Skanska Sweden, Warfvinges Väg 25, 11274 Stockholm, Sweden; thomas.blanksvard@ltu.se

6 Luossavaara-Kiirunavaara Aktiebolag (LKAB), 97437 Luleå, Sweden; faez.sayahi@lkab.com

check for updates

Citation: Mensah, R.A.; Shanmugam, V.; Narayanan, S.; Razavi, S.M.J.; Ulfberg, A.; Blanksvärd, T.; Sayahi, F.; Simonsson, P.; Reinke, B.; Försth, M.; et al. Biochar-Added Cementitious Materials-A Review on Mechanical, Thermal, and Environmental Properties. Sustainability 2021, 13, 9336. https://doi.org/10.3390/ su13169336

Academic Editors: Gonzalo Guirado, Karolina Zalewska Patricio, Luis Cobra Branco, Hugo Cruz and Enzo Martinelli

Received: 4 July 2021

Accepted: 12 August 2021

Published: 20 August 2021

Publisher's Note: MDPI stays neutral with regard to jurisdictional claims in published maps and institutional affiliations.

Copyright: (C) 2021 by the authors Licensee MDPI, Basel, Switzerland. This article is an open access article distributed under the terms and conditions of the Creative Commons Attribution (CC BY) license (https:// creativecommons.org/licenses/by/ $4.0 /)$.
Doktorsexamen Industriellt Anläggningsbyggande, Broar och Byggnadsverk, LCC, 97187 Luleå, Sweden; peter.simonsson@trafikverket.se

8 NovoCarbo GmbH, 56281 Dörth, Germany; b.reinke@novocarbo.com

9 Business Administration and Industrial Engineering, Department of Social Sciences, Technology and Arts, Luleå University of Technology, 97187 Luleå, Sweden; daria.sas@ltu.se

* Correspondence: javad.razavi@ntnu.no (S.M.J.R.); gabriel.sas@ltu.se (G.S.); oisik.das@ltu.se (O.D.)

+ These authors have contributed equally to the manuscript and hence, they both qualify as first authors.

Abstract: The enhanced carbon footprint of the construction sector has created the need for $\mathrm{CO}_{2}$ emission control and mitigation. $\mathrm{CO}_{2}$ emissions in the construction sector are influenced by a variety of factors, including raw material preparation, cement production, and, most notably, the construction process. Thus, using biobased constituents in cement could reduce $\mathrm{CO}_{2}$ emissions. However, biobased constituents can degrade and have a negative impact on cement performance. Recently, carbonised biomass known as biochar has been found to be an effective partial replacement for cement. Various studies have reported improved mechanical strength and thermal properties with the inclusion of biochar in concrete. To comprehend the properties of biochar-added cementitious materials, the properties of biochar and their effect on concrete need to be examined. This review provides a critical examination of the mechanical and thermal properties of biochar and biocharadded cementitious materials. The study also covers biochar's life cycle assessment and economic benefits. Overall, the purpose of this review article is to provide a means for researchers in the relevant field to gain a deeper understanding of the innate properties of biochar imparted into biochar-added cementitious materials for property enhancement and reduction of $\mathrm{CO}_{2}$ emissions.

Keywords: biochar; concrete; mechanical properties; thermal properties; life cycle assessment

\section{Introduction}

Increased $\mathrm{CO}_{2}$ emissions are one of the most serious threats to the environment in recent times. $\mathrm{CO}_{2}$ exists in nature, sustaining the carbon cycle between plants, animals, soil, ocean, and atmosphere. There are natural sources of $\mathrm{CO}_{2}$; however, human activities, especially starting from the industrial revolution, are the primary source of increased $\mathrm{CO}_{2}$ emissions. The rise of industrialisation drastically increased $\mathrm{CO}_{2}$ emissions day by day. For example, in 1755, the measured atmospheric $\mathrm{CO}_{2}$ level was 280 ppm; in 2005, it increased to 380 ppm [1]. In 2019, the concentration was 409.8 ppm [2], which was primarily due to 
energy generation. Human activities in energy generation for fuelling manufacturing industries have contributed significantly to this rise. Among various manufacturing processes, construction-based industries have played a significant role in the global $\mathrm{CO}_{2}$ emissions. The process associated with the manufacturing of cement is energy intensive, emitting high amounts of $\mathrm{CO}_{2}[3,4]$. According to reports, one tonne of $\mathrm{CO}_{2}$ is released into the atmosphere for every tonne of cement manufactured [5]. Cement manufacturing involves several processes; the production, processing, and preparation phases alone account for $7 \%$ of total global $\mathrm{CO}_{2}$ emissions [6]. China is the world's leading cement producer, accounting for half of global cement production; it is no surprise that China reported 823 million metric tonnes of $\mathrm{CO}_{2}$ emissions in 2019 [7]. This increasing rate necessitates the development of strategies to limit $\mathrm{CO}_{2}$ emissions in the cement manufacturing industries.

Globally, research has been carried out to develop mitigation strategies to control $\mathrm{CO}_{2}$ emissions from the cement manufacturing sectors whilst retaining cement's performance. These strategies include changes in raw materials, new production equipment, fuel alterations, etc. [8-12]. In this context, life cycle assessment [13-15] and the effectiveness of alternative bio-based constituents in cement manufacturing were also investigated [16-20]. Additionally, notable studies on the efficacy of waste [14,21-25] and ash-based constituents [26-31] in cement have been reported. Although the addition of biobased constituents is cost effective, it reduces the cement's performance [32]. A few studies have found that the addition of biomass to cement causes its degradation due to the alkaline nature of the cement material [33]. As a result, the durability of cementitious materials is reduced. Furthermore, the presence of cellulosic materials delays cement hydration and reduces the water permeability of concrete $[34,35]$. In ash-based constituents, the presence of organic and inorganic impurities depletes the cement's properties [36,37]. However, converting these biobased constituents to biochar is an efficient method because biochar is sustainable, eco-friendly, contributes to $\mathrm{CO}_{2}$ reduction, and has excellent thermal and mechanical properties [38]. Recent literature on biochar-added cement materials emphasises the role of biochar in governing the mechanical and thermal properties. However, the improvement in thermal and mechanical properties is dependent on various factors such as biochar content, biochar source, biochar preparation parameters, and biochar particle size. All of these factors must be optimised in order to achieve better mechanical and thermal properties. Recently, Malijaee et al. [39] in their review reported biochar's effectiveness in the cement material in terms of workability, hydration, mechanical, and transfer properties of the cement material. In another review paper, Akinyemi and Adesina [40] emphasised the importance of biochar addition in cement material, particularly for carbon sequestration. Despite the fact that there are a few review publications on the application of biochar in cementitious materials, the mechanical and thermal properties have not been critically studied. Therefore, a study that collates information regarding the inherent properties of biochar/concrete, taking into account the LCA assessment and economic benefits is much needed. This review sheds light on the research gap and can be used to gain a better understanding of the science underlying the mechanical and thermal performance of biochar-added cementitious materials.

\section{Biochar}

Organic substances from plant and animal wastes (biomass), especially forestry products, have been undervalued for decades. They were mostly used for fuel production by direct combustion [41,42]. Technological advancement in this area influenced the burning process, which led to the production of bio-derived fuels that could act as alternatives to fossil fuels and a solid by-product. Biochar is the solid residue obtained from the controlled thermal decomposition (pyrolysis) and gasification of biomass under limited oxygen $[43,44]$. Notable control parameters are heating rate, temperature, feed rate, and residence time [45]. Altering the aforementioned parameters and the choice and quality of feedstock affect the structure, chemical composition, and yield of biochar obtained. Biochar is black in colour, but it displays a brown colour when it is not concentrated, rich in carbon, 
has a large specific surface area, and has a porous structure. Aside from carbon, compounds such as ash, nitrogen, oxygen, and sulphur have been identified in biochar [46]. Biochar has been used as a filler in polymeric materials [47,48] for carbon sequestration [49], soil remediation [50], energy storage and conversion purposes [51], etc.

\subsection{Fire, Mechanical, and Thermal Properties of Biochar}

The innate characteristics that facilitate the application of biochar as an admixture in cementitious materials and a filler in composites are the thermal, mechanical, and fire properties. However, there is a paucity of research on the properties of biochar for different feedstock and varying pyrolysis parameters. The moisture content and volatile matter in biochar after the pyrolysis process, which are dependent on the pyrolysis temperature, are the determining factors of its combustibility [45]. Low-temperature biochars have high levels of flammable volatiles [52]. The volatile matter is blocked in the pores of biochar at low temperatures and serves as fuel, thereby increasing the combustibility of the biochar. Increasing the pyrolysis temperature leads to thermal cracking of the biochar, which releases the volatiles in the pores leaving only the carbon skeleton. This action reduces the volatile matter in high-temperature biochars, making it fire resistant. Ronsse et al. [52] investigated the effect of pyrolysis temperature on the volatile matter resident in pine wood, wheat straw, green waste, and dry algae. The results from the study indicated that volatile matter reduced with increasing temperature, as shown in Figure 1. From the figure, it can be understood that the volatile matters are greatly reduced at high temperatures (ca. 500 to $700{ }^{\circ} \mathrm{C}$ ). Zhao et al. [53] made a similar observation when the volatiles in apple tree feedstock reduced from $61 \%$ to $15 \%$ as the temperature increased from 300 to $600{ }^{\circ} \mathrm{C}$. Moreover, moisture content decreases with increasing temperature.

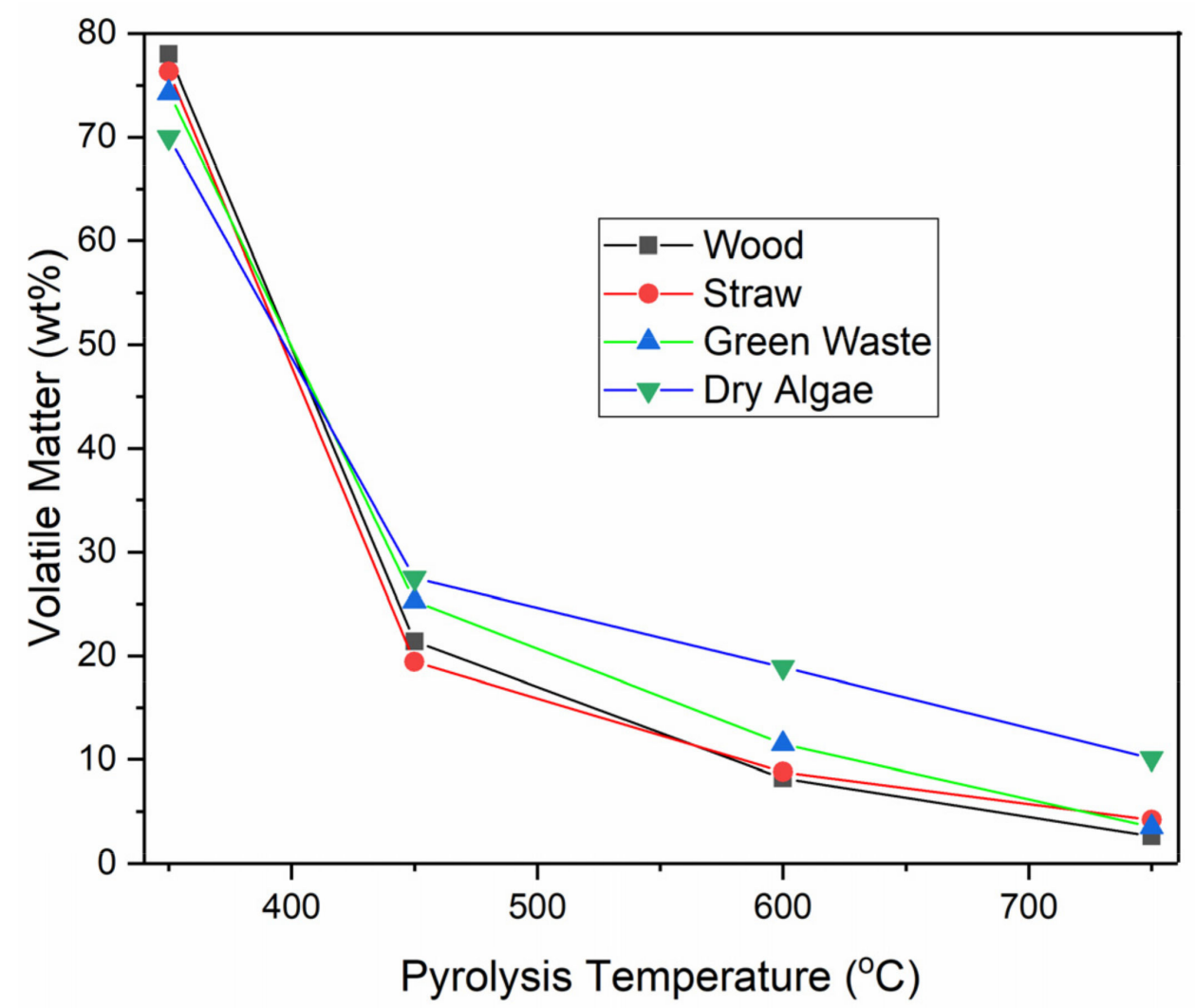

Figure 1. Plot of volatile matter content against pyrolysis temperature for different biochar feedstocks [52]. 
It has been proven by flammability assessments that biochar exhibits lower peak heat release rate (PHRR), time to ignition (TTI), total heat release (THR), and total CO produced, compared to their respective feedstock and conventional materials such as polymers [54]. For instance, in the work of Liu et al. [55], the PHRR, TTI, and THR of bamboo biochar pyrolysed at $300{ }^{\circ} \mathrm{C}$ for $2 \mathrm{~h}$ in the cone calorimeter at $35 \mathrm{~kW} \mathrm{~m}^{-2}$ were $55 \mathrm{~kW} \mathrm{~m}^{-2}, 60 \mathrm{~s}, 6.3 \mathrm{MJ} \mathrm{m}^{-2}$, respectively, compared to $131 \mathrm{~kW} \mathrm{~m}^{-2}, 97 \mathrm{~s}, 27 \mathrm{MJ} \mathrm{m}^{-2}$, respectively, for bamboo.

The mechanical behaviour of biochar varies with pyrolysis temperature, residence time, and feedstock. Kumar et al. [56] conducted a study to analyse the mechanical behaviour of biochar produced from acacia and eucalyptus wood. The authors noticed that the compressive and impact strengths of both materials decreased with temperature up to $600{ }^{\circ} \mathrm{C}$ and then increased. However, eucalyptus biochar showed higher mechanical properties, as compared to acacia. Additionally, the stiffness, hardness, and Young's modulus of biochar increases with pyrolysis temperature and residence time $[53,57]$. At low temperatures and residence time, pyrolysis may be incomplete therefore the biochar possesses a defective structure. However, at elevated temperatures and residence time, the volatile products and functional groups reduce, and the total inorganic carbon content increases. This tends to enhance the mechanical properties of high-temperature biochars.

The thermal characteristics of biochar differ by feedstock and pyrolysis conditions. Biochar exhibits excellent thermal properties compared to the parent biomass. These were the findings from the investigations of the thermal properties of pine wood, Chinese fir wood, Chinese fir bark, bamboo leaves, bamboo sawdust, Miscanthus, pecan shells, and rice straw-derived biochar in the work of Yang et al. [58]. The poor thermal properties are partly due to the anisotropic nature and high density of the feedstock. The pyrolysis process produces a porous structured char with low density, which decreases the thermal conductivity of the resultant product. Although the thermal conductivity of biochar also depends on the grain direction, an increase in the pyrolysis temperature up to about $700{ }^{\circ} \mathrm{C}$ reduces the anisotropy especially for wood-based biochar [59]. This was demonstrated in the work of Gupta et al. [60], where the thermal conductivities and specific heat of softwood, softwood bark, and softwood char were estimated with a modified fitch apparatus and a differential scanning calorimeter, respectively. The results showed that the thermal conductivity of softwood was two times that of the softwood char, indicating the higher thermal resistance of the biochar. Additionally, the thermal conductivity of wood in the longitudinal direction, which ranged between 0.2 and $0.45 \mathrm{~W} / \mathrm{m} \mathrm{K}$ reduced to $0.08 \mathrm{~W} / \mathrm{m} \mathrm{K}$ after converting it to biochar [61]. It was observed in the work of Dupont et al. [62] that the specific heat capacity of biomass is higher than biochar, and it increases with increasing temperature. In line with this observation, between the temperatures of 37 and $140{ }^{\circ} \mathrm{C}$, the specific heat capacities of softwood and its biochar increased from 1172 to $1726 \mathrm{~J} / \mathrm{kg} \mathrm{K}$ and 768 to $1506 \mathrm{~J} / \mathrm{kg} \mathrm{K}$, respectively. Additionally, Jiang et al. [63] confirmed that the coefficient of thermal diffusion of biochar is lower than that of concrete; however, it increases with increasing temperature. Due to the relatively lower thermal conductivity and thermal diffusivity, as well as high thermal resistance, biochar could be considered a thermal insulation material for regulating humidity in buildings.

\subsection{Concrete Background}

Concrete is a ubiquitous and versatile material. It is a major component of the construction industry [64]. The utilisation of concrete for several types of structures has placed a significant demand on the material, thus increasing its production rate. The global market for concrete is estimated to increase by a 12\% compound annual growth rate in 2021 with expected growth to about USD 441.7 billion by 2023 [65]. Concrete is a composite material which comprises cement, water, admixture, and aggregates in proportions suitable for the intended purpose [66]. Cement is the main constituent of concrete that acts as a bonding agent and hardener. Despite the usefulness of cement, the industry is one of the leading contributors to $\mathrm{CO}_{2}$ emissions. Admixtures including fly ash, steel fibre, etc. enhance 
the properties of concrete for improved performance, and aggregates including sand and stones are used as fillers for retaining the strength of concrete [67].

Cement production contributes about $7 \%$ of the global $\mathrm{CO}_{2}$ emissions. Interestingly, out of the four main constituents of concrete, cement produces $90 \%$ of the emissions [66]. The production of a tonne of cement leads to the emission of a tonne of $\mathrm{CO}_{2}$. It is, therefore, of utmost importance to supplement concrete with natural constituents in order to impart sustainability. Lu et al. [68] studied the effect of fly ash on the compressive strength of concrete. According to the study, the addition of 10\% fly ash to concrete increased the compressive strength, durability, and workability. However, any further increments reduced the strength. Other natural constituents such as rice husk ash, hen egg shells, waste sludge, waste glass, foundry waste, as well as waste tires and biochar, have been used as additives in concrete to improve its insulation ability and strength [66]. Kriker et al. [69] stated that the addition of biomass in its raw state to concrete had the tendency of minimising the durability, hence promoting the use of biochar (pyrolysed biomass) as an effective admixture in concrete.

\section{Review of Biochar/Concrete Composites}

\subsection{Microstructure and Interfacial Bonding in Biochar/Cementitious Materials}

Synthetic fibres in concrete is susceptible to wall effect (formation of a thin water film between fibre and matrix interface), leading to reduced bonding. However, several surface treatment methods, such as plasma treatment, acid treatment, and chemical treatment, have been used to improve the interface by increasing the surface roughness of the fibre. These methods were effective in improving bonding and concrete strength. However, the introduction of functional components such as biochar can be an efficient method that can reduce costs and time when compared to other treatment processes. The biochar particle can absorb moisture, and its porous nature may be advantageous for matrix permeability, resulting in increased strength in the concrete. In line with this, Gupta et al. [70] investigated the effect of biochar coating on PP fibre reinforcement in concrete. The biochar used was created by pyrolysing wood sawdust at a low temperature of $300{ }^{\circ} \mathrm{C}$. There were two types of biochar used: fresh biochar and $\mathrm{CO}_{2}$ saturated biochar, both with a size of about $300 \mu \mathrm{m}$. The fibres were coated by dipping them into a paste made of cement, biochar, and water. The coating ratio followed was 1:3:1:2.5 (PP fibre, biochar, cement, and water, respectively). In the single fibre pull-out test, the fresh biochar coated fibre had the highest pull-out load of $14.65 \mathrm{~N}$, which was $45 \%$ and $33 \%$ higher than the fibre without coating and the fibre with $\mathrm{CO}_{2}$ saturated biochar, respectively (both the coated fibres were cured for 28 days). These findings show that biochar, when used as a coating material, is an effective material for improving the bonding of synthetic fibres with the concrete matrix. This improved bonding could account for the fresh biochar coated PP fibre-reinforced concrete's higher flexural strength (ca.14 MPa after 28 days of curing) when compared to uncoated PP fibre-reinforced concrete (ca.11 MPa after 28 days of curing). Another significant finding in this investigation is the effect of curing on strength. When the curing period of the biochar coated PP fibres added concrete was extended, the pull-out load increased. Figure 2 depicts the variation in pull-out load as a function of curing. This increase could be due to a decrease in moisture content during curing, however, the underlying mechanism was not captured in the research with regard to the three different fibre-added concretes.

Gupta et al. [71] found that biochar-ereduce the formation of voids and porosity. These were the main reasons for the development of seepage resistance in the biochar-based bonding agent. The presence of a ridge-shaped surface, as well as the porous structure in the biochar, was identified by the authors as the primary reason for the improved bonding with the cementitious matrix. Figure $3 a, b$ shows the porous and ridge surface in biochar. The porous ridge surface of the biochar facilitates the infiltration of the cementitious matrix, resulting in strong interfacial bonding. 


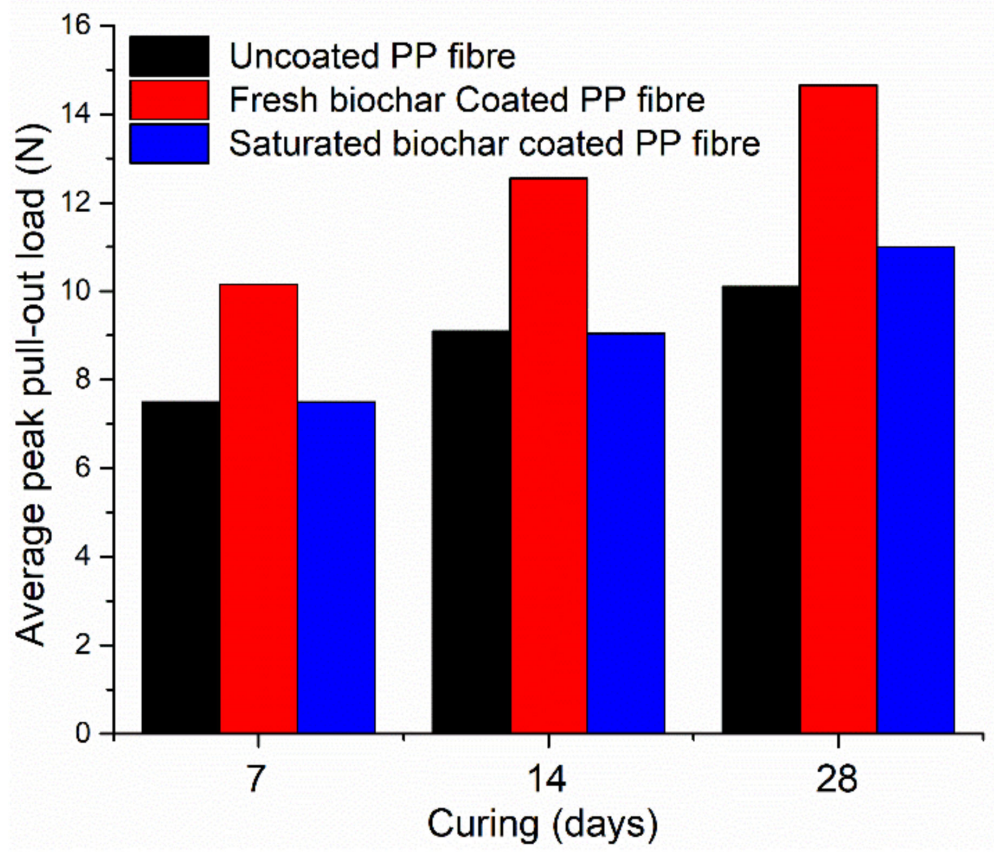

Figure 2. Peak pull-out load variation on biochar coated PP fibre-reinforced cement (data taken from [70]).
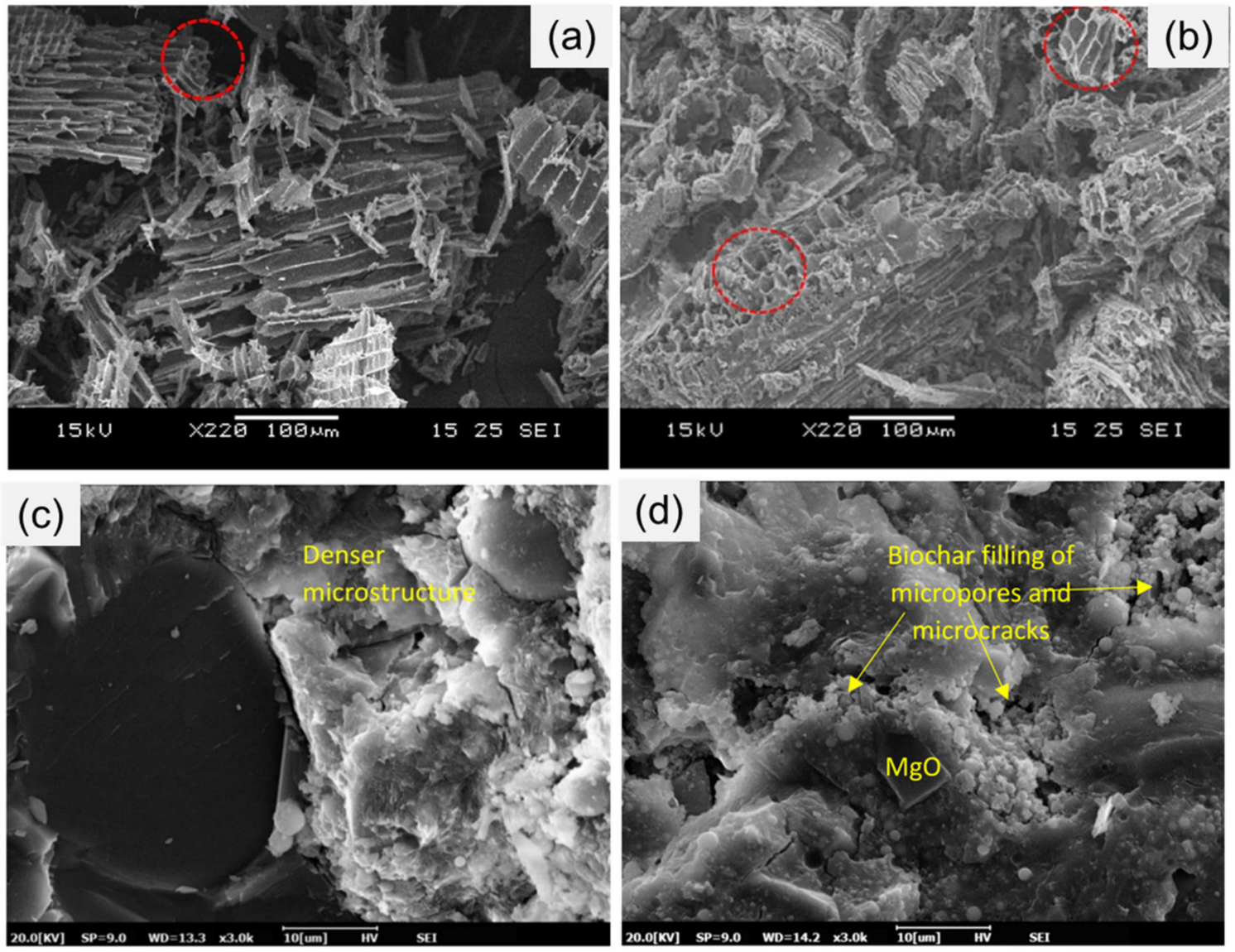

Figure 3. (a,b) porous and ridge surface in biochar [71]; (c) denser microstructure [72]; (d) biochar filling micro pores and cracks [72]. 
A stronger interfacial bonding and a more compact microstructure are illustrated in Figure 3c. The denser microstructure is a result of the reaction between the magnesium phosphate cement and biochar. According to Ahmad et al. [72], the biochar particles filled the micropores and voids in the magnesium phosphate mortar, as seen in Figure 3d. In this study, biochar was added at three different weight percentages $(0.5 \%, 1.0 \%$, and $1.5 \%)$ and its compressive and flexural strength were measured. After 180 days of curing, the biochar mortar with $1.5 \%$ biochar exhibited maximum compressive (102 $\mathrm{MPa}$ ) and flexural strength (ca.13 MPa). This was mainly due to the denser microstructure that resulted from the $1.5 \%$ biochar addition. The denser microstructure created a surface with less voids and pores, which enhanced the compressive strength.

According to Wang et al. [73], the addition of biochar particles increases hydration, which leads to densification. Generally, hydration occurs in cement mixtures; the addition of biochar improves the rate of hydration. In Figure 4, the hydration heat rate curve of biochar-added cement was compared to that of regular cement. Based on the hydration rate, the heat release rate of cement was divided into five stages: initial reaction period, induction period, acceleration period, deceleration period, and slow reaction period. The effect of biochar on the hydration rate can be clearly seen during the acceleration and deceleration periods. It is important to note that the biochar had no effect on the hydration timing or rate, but there was a slight increase (ca. $0.05 \mathrm{~mW} / \mathrm{g}$ ) in the heat release of cement, which can be attributed to moisture control. This hydration mechanism is critical in the development of the densified microstructure in the cementitious matrix and was well described in [74]. According to Gupta et al. [74], after adding biochar to the cementitious mixture, biochar fills the micropores and voids between the cement and sand grains. Due to the presence of hydroxyl functional groups, biochar attracts cement particles and forms a cluster around them. Clustering results in nucleation, which improves hydration by attracting more biochar particles. This causes hydration products to precipitate on the surfaces of the biochar clusters. This mechanism is illustrated in Figure 4. As a result, biochar evolves into an active filler material that increases densification in the cementitious matrix. This demonstrates that biochar is an active filler material that promotes densification in the cementitious matrix.

(a)

Cement particles Hydration around cement particles

(a)

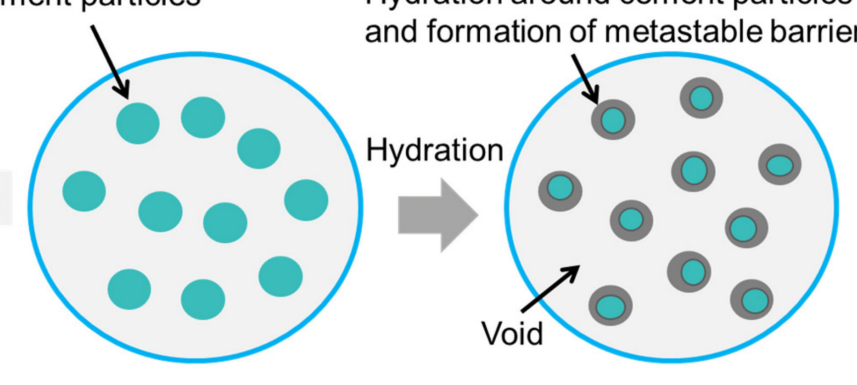

(b)

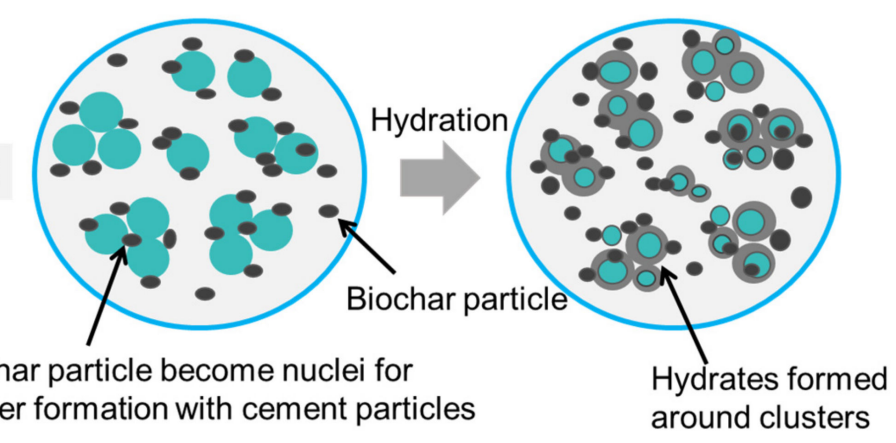

Figure 4. Schematics showing hydration product formation in (a) cement-only system and (b) system containing cement and biochar [74]. 
The temperature at which the biochar is pyrolysed is also important in achieving improved bonding between biochar and matrix. For instance, Wang et al. [75] created biochar blocks produced at $500{ }^{\circ} \mathrm{C}$ and $700{ }^{\circ} \mathrm{C}$. The biochar produced at $700{ }^{\circ} \mathrm{C}$ had larger pores and higher specific surface area than the low-temperature biochar, which facilitates increased bonding due to increased matrix infiltration. The removal of volatile matter in the biochar resulted in the formation of larger pore sizes in the high-temperature biochar. It should also be noted that the larger the pore size and specific surface area are, the greater the moisture retention ability of the cementitious mortar is [76]. The water retention property of biochar is beneficial in further enhancing the curing of the cementitious matrix. The biochar releases the absorbed moisture, which initiates internal curing under a humidity gradient, assisting in the restoration of moisture lost during internal or external drying. This could reduce the risk of plastic, autogenous, and drying shrinkage in concrete as well as improving the hydration and moisture balance within the cementitious matrix. In line with this, Gupta and Kua [76] stated that biochar particles preserved more moisture, which aided internal curing in the absence of external water. In this study, the authors used pre-soaked biochar, which increased compressive strength by $40 \%$ and $30 \%$, respectively, as compared to neat mortar and un-soaked biochar-added mortar. The authors also found that internal curing via biochar has a densifying effect on mortar paste.

The bonding characteristics can also vary depending on the feedstock material used to make the biochar. For instance, Zeidabadi et al. [77] investigated the efficacy of two different biochars (rice husk biochar and bagasse biochar) produced at the same pyrolysis temperature of $700{ }^{\circ} \mathrm{C}$. The authors noted differences in the mechanical properties of two different biochar-added concretes developed using the same process and weight percentage. The author concluded that this variation was caused by differences in the structural properties of the biochar. When compared to rice husk biochar, bagasse biochar has a larger specific surface area. The estimated specific surface area of the rice husk biochar was $37.5 \mathrm{~m}^{2} / \mathrm{g}$, and for the bagasse biochar, it was $52.3 \mathrm{~m}^{2} / \mathrm{g}$. The higher specific surface area of the bagasse biochar contributed to increased interfacial adhesion area and mechanical strength. This study also demonstrated the efficacy of biomass treatment. Before the pyrolysis process, the biomasses were treated with hydrochloric acid to remove metal contaminants such as $\mathrm{K}^{+}, \mathrm{Ca}^{2+}$, and $\mathrm{Mg}^{2+}$, as well as to change the physical and chemical structure of the biomass. The mechanical strength of the treated and untreated biochar concrete samples differed. For instance, the authors observed a $20 \%$ increase in compressive strength in untreated rice husk biochar when compared to neat concrete, but a $36 \%$ increase was observed between pre-treated rice husk biochar and neat concrete. These noticeable disparities in properties emphasise the degree of variation caused by the structural differences in the feedstock material. It is clear from this investigation that the feedstock material used, and its properties have a significant influence on developing bonding in the cementitious matrix. The proper mixing ratio of biochar cement mixture should be maintained during processing, as this may affect the rheological properties of the mixture, which directly contributes to poor bonding and lower strength.

\subsection{Mechanical Properties of Biochar/Cementitious Materials \\ 3.2.1. Compression Strength}

The compressive strength of biochar-added cementitious materials varies according to biochar type, content, and pyrolysing temperature. The trend in biochar addition was uneven, which could be attributed to differences in biochar feedstock properties. For instance, Akhtar and Sarmah [66] investigated the compressive strength of biochar produced from three different feedstocks (poultry litter, rice husk, and pulp/paper mill sludge). The poultry litter biochar was made at $450{ }^{\circ} \mathrm{C}$, while the rice husk and pulp/paper mill sludge biochar were made at $500{ }^{\circ} \mathrm{C}$. Concrete blocks were created at $0.1 \%, 0.25 \%$, $0.5 \%, 0.75 \%$, and $1 \%$ biochar in relation to the total volume of concrete. Concretes that had been cured for 7, 14, and 28 days were tested. Biochar-added concrete had lower compressive strength than non-biochar-added concrete. The poultry litter biochar concrete 
cured after seven days had the lowest strength (ca.14 MPa), which was $41 \%$ lower than the control cured after seven days. Increased curing time resulted in a significant increase in strength. For example, an increase of approximately $31 \%$ was observed on pulp/paper mill sludge biochar concrete cured after 28 days, compared to seven days. In this study, lower strength was found in the concrete with less biochar addition. As a result, the author advocated for a use of a higher percentage of biochar in concrete production. However, this study used a biochar variation of $0.1,0.25,0.5,0.75$, and $1 \%$. While this variation is minor, the addition of higher concentrations of biochar could help elucidate the contradictions of high biochar percentages in concrete. The findings from the investigation were also supported by the observations of Cuthbertson et al. [78]. In this study, dry distiller grains from the bio-ethanol industry were pyrolysed at 500 and $600{ }^{\circ} \mathrm{C}$ to produce biochar. The compressive strength of biochar/concrete added at 1.2 and $3 \mathrm{wt} \%$ by replacing sand and aggregate was investigated in this study. The findings of this study showed no significant trend, but a slight increase was observed after the addition of biochar. The addition of 3 wt. \% biochar pyrolysed at $500{ }^{\circ} \mathrm{C}$, demonstrated maximum strengths of 21 and $22 \mathrm{MPa}$ when sand and aggregate were replaced, respectively. In contrast to this investigation, Ahmad et al. [79] found that adding less biochar to the bamboo biochar cement composite increased compressive strength. Biochar/cement was created in three different biochar content levels $(0.05 \%, 0.08 \%$, and $0.2 \%)$. It should be noted that in this study, biochar was pyrolysed at $850{ }^{\circ} \mathrm{C}$, then annealed at $850{ }^{\circ} \mathrm{C}$ with $\mathrm{NaOH}$-treated biomass. Among all the biochar/cement, $0.08 \%$ biochar/cement resulted in increased strength. The compressive strength of composites containing $0.08 \mathrm{wt}$.\% biochar/cement ranged between $85 \mathrm{MPa}$ and $100 \mathrm{MPa}$. This maximum enhancement could be attributed to the treatment effect, which removed the volatile matter and aided in the formation of larger pores in the biochar. Additional annealing of the biochar could result in the formation of less amorphous and more graphitised, carbonised bamboo particles. This study adds another dimension to the investigation of the properties of biochar in influencing compressive strength. In a study by Gupta et al. [71], $1 \mathrm{wt} . \%$ and $2 \mathrm{wt}$ \% biochar addition was found to be the optimum for increasing the compressive strength of cement mortar. When compared to non-biocharadded mortar, a significant increase of $22 \%$ and $27 \%$ was observed on the biochar-added (pyrolysed at $500{ }^{\circ} \mathrm{C}$ ) mortar cured at seven days. Following that, biochar addition beyond $2 \%$ resulted in a reduction in strength.

Zeidabadi et al. [77] reported maximum strength on the $5 \mathrm{wt} . \%$ bagasse biochar-added concretes. In contrast to the work of Zeidabadi et al. [77], Mrad and Chehab [80] observed a decrease in compressive strength when high percentages of biochar were used $(5,10$, 15,25 , and $40 \mathrm{wt} . \%$ ). The authors noted a loss of $20-98 \%$ compressive strength in the biochar mortar when compared to mortar without biochar. The author explained that this decrease was due to biochar's high water retention capacity. The water absorbed by the biochar has an effect on the mortar properties, lowering the compressive strength. Based on these findings, it is possible to conclude that the compressive strength of the concrete varies with biochar feedstock, which influences the structure of the biochar. According to Sirico et al. [81], the compressive strength will be greatly affected by the physical and chemical properties of the feedstock material. By comparing the findings of these studies, it is possible to conclude that the feedstock., pyrolysis temperature, properties of the resultant biochar and particle size can significantly affect the compressive strength of biochar cementitious materials, regardless of the biochar content.

Few researchers have investigated the synergistic effect of biochar with other concrete constituents. Dixit et al. [82] developed ultra-high performance concrete using biochar as a partial replacement material for quartz powder. The biochar used in this study was created through the pyrolysis of saw dust (pyrolysis temperature $500{ }^{\circ} \mathrm{C}$ ). Concrete samples were made by incorporating biochar at $2 \%$ and $5 \%$ by weight of cement. Both the $2 \mathrm{wt} . \%$ and 5 wt. $\%$ additions of biochar had a negative effect on compression strength. After 28 days of curing, the strength of the $2 \%$ and $5 \%$ biochar concrete was reduced by about $13 \%$ and $14 \%$, respectively, when compared to the non-biochar-added concrete. This was due to 
the biochar's poor properties in comparison to the other constituents (silica fume, silica sand, and quartz powder) in the ultra-high-performance concrete. The biochar acted as a weak zone in the cement matrix, resulting in low compression strength. The author, on the other hand, suggested experimenting with different biochar feedstock to examine their influence on strength. In another work, Mo et al. [83] investigated the synergetic impact of biochar and $\mathrm{MgO}$ on the compressive strength of concrete. The biochar produced from the pyrolysis of weed tree under $600{ }^{\circ} \mathrm{C}$ was used and added at $2 \mathrm{wt} . \%$, whereas the $\mathrm{MgO}$ was added at 4 and $8 \mathrm{wt} . \%$. The addition of $\mathrm{MgO}$ showed a reduction in the strength, and an increase in the $\mathrm{MgO}$ reduced the strength further. Nonetheless, the addition of biochar to $\mathrm{MgO}$ increased the strength. After 98 days of curing, the addition of biochar and $8 \%$ $\mathrm{MgO}$ to concrete increased the strength by $6 \%$ with respect to the reference concrete. This increase was achieved as a result of the internal curing effect of biochar, which aided in cement hydration.

Interestingly, Navaratnam et al. [84] tested the compressive strength of the biochar mortar (28 days cured) after heating at three different temperatures $\left(200{ }^{\circ} \mathrm{C}, 450{ }^{\circ} \mathrm{C}\right.$, and $700{ }^{\circ} \mathrm{C}$ ). Figure 5 depicts the compressive strength variation of the concrete samples tested at normal and elevated temperatures. Biochar mortar was created in three different biochar proportions ( $5 \%, 10 \%$, and $20 \%$ of cement weight). The compressive strength of the biochar mortars at room temperature was $35,39,28$, and $16 \mathrm{MPa}$ for $0 \%, 5 \%, 10 \%$, and $20 \%$ biochar addition, respectively. When the mortars were tested at high temperatures, it lost strength. When compared to the room temperature testing, a $20 \%$ biochar-added mortar showed a $19 \%$ reduction in strength at $200{ }^{\circ} \mathrm{C}$ and a $75 \%$ reduction at $700{ }^{\circ} \mathrm{C}$. This decrement was caused by the development of internal and external microcracks as a result of the degradation and damage of the calcium-silicate-hydrate $(\mathrm{C}-\mathrm{S}-\mathrm{H})$ gel structure and calcium hydroxide $(\mathrm{CH})$ in the cementitious matrix, which led to dehydration. The graph shows that the $5 \%$ biochar has a significant increase in strength and a reduction in residual compressive strength at high temperatures. Thus, for high-temperature applications, concrete containing $5 \%$ biochar can be effective in both increasing strength and mitigating residual compressive strength loss at high temperatures.
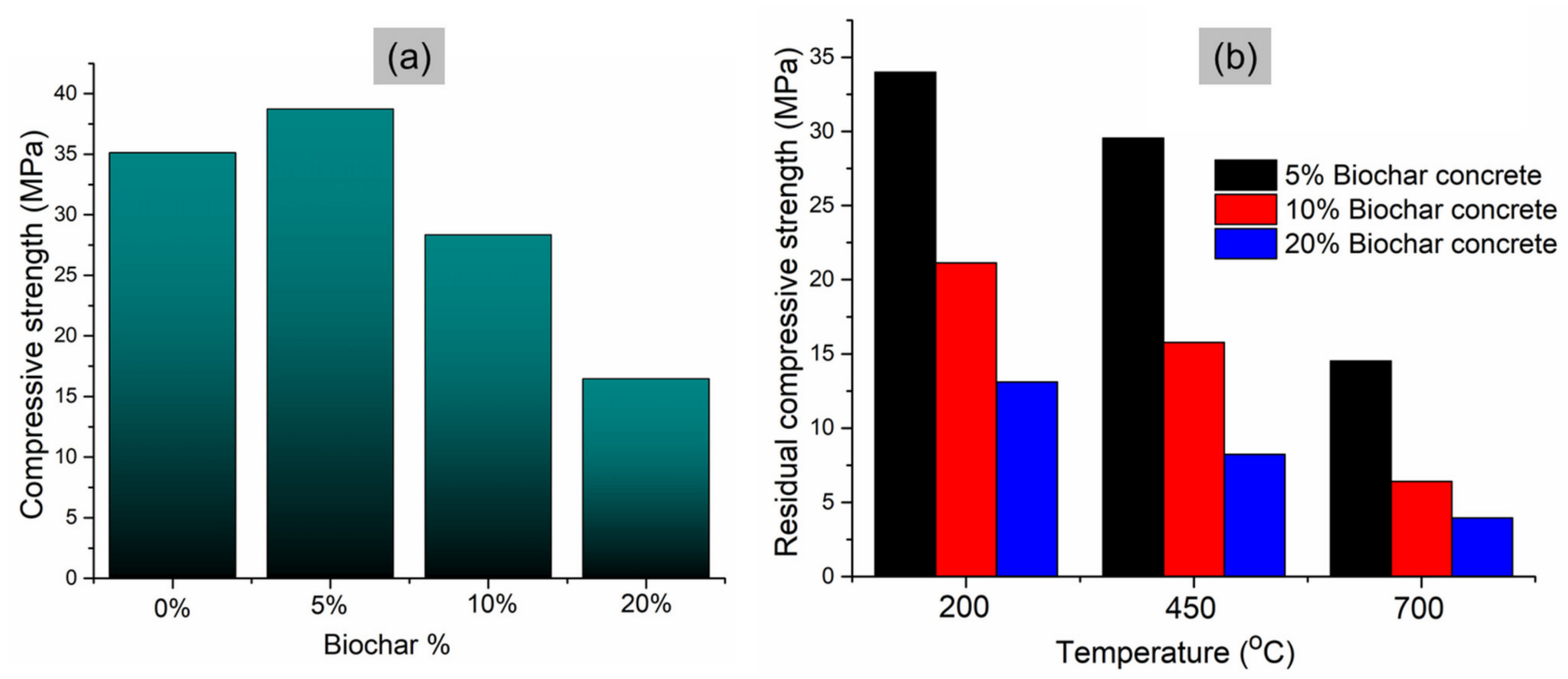

Figure 5. (a) Compressive strength at room temperature; (b) Residualresidual compressive strength at elevated temperature (data were taken from ref. [84]).

Chin et al. [85] investigated the influence of activated biochar on the compressive strength of concrete. The biochar was created by pyrolysing oil palm kernel shell at $500{ }^{\circ} \mathrm{C}$ and then activating it with steam for $2 \mathrm{~h}$ at a flow rate of $150 \mathrm{~cm}^{3} / \mathrm{min}$ and a temperature of $900{ }^{\circ} \mathrm{C}$. After 28 days of curing, the activated biochar concrete reached a maximum strength of $50 \mathrm{MPa}$. This result was similar to the findings of [86]. Wu et al. [86] used 
peach and apricot shells that were first heated at $200{ }^{\circ} \mathrm{C}$ for $1 \mathrm{~h}$ and then at $550{ }^{\circ} \mathrm{C}$ for $4 \mathrm{~h}$. The compressive strength of the peach shell and apricot shell biochar-added mortar was compared to the compressive strength of the peach shell and apricot shell mortar. When compared to fresh peach shell and apricot shell mortar, carbonised peach shell and apricot shell mortar increased compressive strength by 53\% and 33\%, respectively. The strength increase in both studies was caused by the formation of a rough surface in the activated biochar, which supported the increase in interfacial strength. Based on the findings of these studies, it is possible to conclude that activating biochar is another method of improving bonding, which could lead to an increase in mechanical strength.

Praneeth et al. [87] explored the effect of replacing 10-40\% of sand in concrete with biochar derived from poultry litter on the compressive strength. The results indicated that the compressive strength of the samples decreased drastically with the addition of biochar. A $21 \%$ decrease was observed when 10\% biochar was added. Between 10 and 30\%, the reduction was approximately $12 \%$, and the lowest compressive strength recorded was with $40 \%$ biochar content. The reduction was due to the high-water retention capacity of biochar, compared to cement and sand. The water fills almost all the pores of the biochar at lower concentrations producing denser composites. However, at higher biochar proportions, the volume occupied by the water molecules decreases, compared to the number of pores; hence, the porosity of the biochar/concrete composite increases, resulting in a decrease in the compressive strength. Similar observations were made by Gupta et al. [76]. Figure 6 is a matrix of the composite, showing high biochar content (a) and low biochar content (b). (c) and (d) show the hydration mechanism in the pores of the biochar from (a) and (b), respectively. Table 1 shows the maximum compressive strength of the biochar-made cementitious material.

(a)

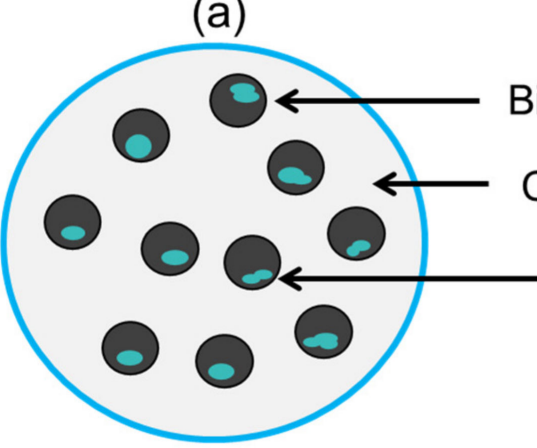

Biochar particle

Cement matrix

Hydration products

Empty pores

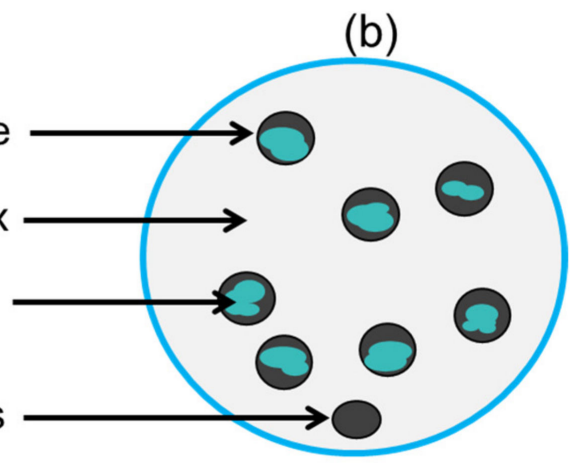

(c)

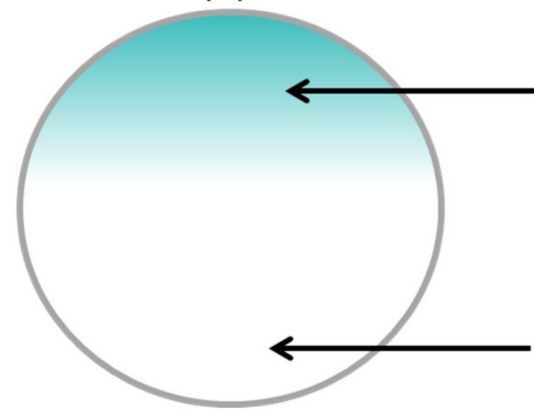
Hydration
products

(d)
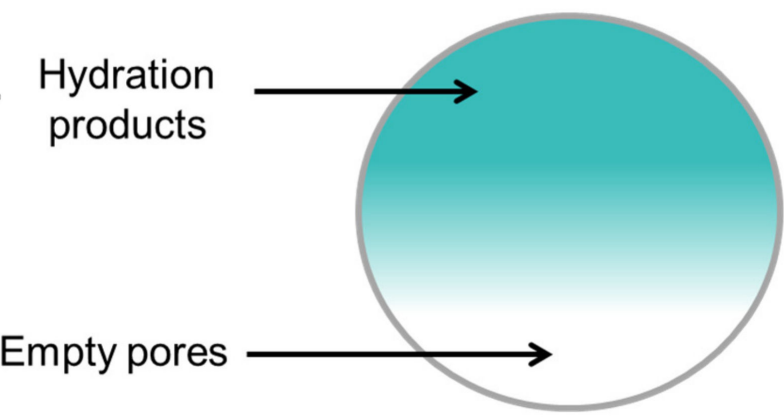

Figure 6. Hydration effect of biochar and concrete [87]. (a)—cement mortars with high biochar content, (b)—cement mortars with high biochar content, $(\mathbf{c}, \mathbf{d})$ - hydration products and empty pores available in each case representing volume of pores. 
Table 1. Compressive strength reported on different biochar/cementitious materials.

\begin{tabular}{|c|c|c|c|c|c|c|c|c|c|}
\hline \multirow{2}{*}{$\begin{array}{c}\text { Construction } \\
\text { Material }\end{array}$} & \multirow{2}{*}{ Biochar Source } & \multirow{2}{*}{$\begin{array}{l}\text { Bio Content } \\
\text { and Size }\end{array}$} & \multirow{2}{*}{ Pyrolysis Conditions } & \multicolumn{6}{|c|}{ Compressive Strength (MPa) } \\
\hline & & & & 1 Day Curing & 3 Days Curing & 7 Days Curing & 14 Days Curing & 28 Days Curing & 30 Days Curing \\
\hline Cement Mortar & Rice husk [88] & $8 \%$ and $2-7 \mu \mathrm{m}$ & $\begin{array}{l}\text { Pyrolysis temperature is } 500{ }^{\circ} \mathrm{C} \text { at a } \\
\text { rate of } 1{ }^{\circ} \mathrm{C} / \mathrm{s}\end{array}$ & - & - & $55^{*}$ & - & $65^{*}$ & - \\
\hline $\begin{array}{c}\text { Ordinary Portland } \\
\text { Cement }\end{array}$ & Poultry litter [66] & $0.1 \%$ & $\begin{array}{l}\text { Slow pyrolysis of } 450^{\circ} \mathrm{C} \text { and } \\
\text { residence time is } 20 \mathrm{~min}\end{array}$ & - & - & $21^{*}$ & $27^{*}$ & $33 *$ & - \\
\hline $\begin{array}{c}\text { Ordinary Portland } \\
\text { Cement }\end{array}$ & $\begin{array}{l}\text { Pulp and Paper mill } \\
\text { biochar [66] }\end{array}$ & $0.1 \%$ & $\begin{array}{l}\text { Pyrolysis at } 500^{\circ} \mathrm{C} \text { using } \\
\text { high-temperature gasifier }\end{array}$ & - & - & $27^{*}$ & $31^{*}$ & $36^{*}$ & - \\
\hline $\begin{array}{l}\text { Ordinary Portland } \\
\text { Cement }\end{array}$ & Rice husk [66] & $0.1 \%$ & $\begin{array}{l}\text { Slow pyrolysis at } 500^{\circ} \mathrm{C} \text { and } \\
\text { residence time is } 20 \mathrm{~min}\end{array}$ & - & - & $26^{*}$ & $30 *$ & $35 *$ & - \\
\hline Cement Mortar & Mixed wood [89] & $1 \%$ and $5-200 \mu \mathrm{m}$ & $\begin{array}{l}\text { Pyrolysis at a temperature of } 500^{\circ} \mathrm{C} \\
\text { and residence time is } 45-60 \mathrm{~min} \text {. } \\
\text { Heating rate is } 10^{\circ} \mathrm{C} / \mathrm{min}\end{array}$ & - & - & $40 *$ & - & $58^{*}$ & - \\
\hline Cement Mortar & Food waste [89] & $1 \%$ and $5-200 \mu \mathrm{m}$ & $\begin{array}{l}\text { Pyrolysis at a temperature of } 500^{\circ} \mathrm{C} \\
\text { and residence time is } 45-60 \mathrm{~min} . \\
\text { Heating rate is } 10^{\circ} \mathrm{C} / \mathrm{min}\end{array}$ & - & - & $36^{*}$ & - & $54^{*}$ & - \\
\hline Cement Mortar & Rice waste [89] & $2 \%$ and $5-200 \mu \mathrm{m}$ & $\begin{array}{l}\text { Pyrolysis at a temperature of } 500^{\circ} \mathrm{C} \\
\text { and residence time is } 45-60 \mathrm{~min} \text {. } \\
\text { Heating rate is } 10^{\circ} \mathrm{C} / \mathrm{min}\end{array}$ & - & - & $36^{*}$ & - & $45^{*}$ & - \\
\hline Cement Mortar & Saw dust [90] & $1 \%$ and $0.92-100 \mu \mathrm{m}$ & $\begin{array}{l}\text { Pyrolysis temperature is } 500{ }^{\circ} \mathrm{C} \text { and } \\
\text { heating rate is } 10^{\circ} \mathrm{C} / \mathrm{min}\end{array}$ & 40.97 & - & - & - & $\begin{array}{l}70.54 \text { (Moist curing) } \\
66 \text { (Air curing) }\end{array}$ & \\
\hline $\begin{array}{l}\text { Ordinary Portland } \\
\text { Cement }\end{array}$ & $\begin{array}{c}\text { Chemically treated, } \\
\text { Pyrolysed, and annealed } \\
\text { bamboo [79] }\end{array}$ & $0.08 \%$ and $1-2 \mu \mathrm{m}$ & $\begin{array}{l}\text { Pyrolysis temperature is } 850^{\circ} \mathrm{C} \text { and } \\
\text { at a heating rate of } 1{ }^{\circ} \mathrm{C} / \mathrm{min}\end{array}$ & - & - & - & - & $97^{*}$ & \\
\hline Ordinary cement & Shell fish biowaste [91] & $0.1 \%$ & $\begin{array}{l}\text { Pyrolysis temperature is } 800{ }^{\circ} \mathrm{C} \text { and } \\
\text { at a heating rate of } 5{ }^{\circ} \mathrm{C} / \mathrm{min}\end{array}$ & 21.11 & - & - & - & - & - \\
\hline Cement mortar & Mixed sawdust [76] & $2 \mathrm{wt} \%$ and $5-500 \mu \mathrm{m}$ & $\begin{array}{l}\text { Pyrolysis between } 300-500^{\circ} \mathrm{C} \text { and at } \\
\text { a heating rate of } 10^{\circ} \mathrm{C} / \mathrm{min}\end{array}$ & - & - & $67^{*}$ & $70^{*}$ & $73^{*}$ & - \\
\hline $\begin{array}{l}\text { Ordinary Portland } \\
\text { cement }\end{array}$ & $\begin{array}{l}\text { Pre-treated Bagasse and } \\
\text { Rice husk [77] }\end{array}$ & $5 \mathrm{wt} \%$ & $\begin{array}{c}\text { Pyrolysis temperature at } 700^{\circ} \mathrm{C} \text { for } \\
2 \text { hrs residence time and at a heating } \\
\text { rate of } 10^{\circ} \mathrm{C} / \mathrm{min}\end{array}$ & - & - & - & - & $\begin{array}{l}\text { Pre-treated rice } \\
\text { husk-50 MPa } \\
\text { Pre-treated } \\
\text { Bagasse-55 MPa }\end{array}$ & - \\
\hline Cement and flyash & Corn Stover [92] & $\begin{array}{c}4 \mathrm{wt} \% \text { and } \\
4.65-144 \mu \mathrm{m}\end{array}$ & $\begin{array}{l}\text { Pyrolysis temperature is } 550^{\circ} \mathrm{C} \text { and at } \\
\text { a heating rate of } 15^{\circ} \mathrm{C} / \mathrm{min}\end{array}$ & - & $40^{*}$ & - & $38^{*}$ & - & - \\
\hline Cement Mortar & Wood chips [81] & $1 \mathrm{wt} \%$ and $38 \mu \mathrm{m}$ & $\begin{array}{l}\text { Pyrolysis temperature is between } \\
200 \text { and } 500^{\circ} \mathrm{C} \text { and gasification } \\
\text { temperature is } 900^{\circ} \mathrm{C}\end{array}$ & - & $79 *$ & - & $90 *$ & - & - \\
\hline
\end{tabular}




\subsubsection{Flexural Strength}

Cosentino et al. [93] investigated the influence of the biochar process parameters (production process, temperature, heating rate, pressure) on the tensile strength of the biochar concrete composite. The softwood biochar was added at $0.8 \%, 1 \%$, and $2 \%$ of the weight of cement. The concrete (tested after 7 and 28 days) on the addition of biochar showed enhancement in the flexural strength when compared to the reference concrete; however, there was no significant difference in $0.8 \%$ and $1 \%$ addition. On 28 days of curing, $0.8 \%$ and $1 \%$ biochar concrete had the flexural strength of 2.48 and $2.49 \mathrm{MPa}$, and for 7 days of curing, it was 2.16 and $2.24 \mathrm{MPa}$, respectively. The authors reported that the higher specific surface area of the biochar was the main reason for the increase in flexural strength, which contributed to the enhanced interaction with the matrix. Restuccia and Ferro $[94,95]$ studied the flexural properties of hazelnut shell and coffee powder biochar concrete. Pyrolysis was performed at $800{ }^{\circ} \mathrm{C}$ and added to the cement at $0.5,0.8$, and $1 \%$ concentrations. Flexural strength for the hazelnut shell biochar concrete increased up to $0.8 \%$ biochar addition, and $1 \%$ biochar addition resulted in a slight decrease (on 7 days curing). The flexural strength of the reference concrete was $2.12 \mathrm{MPa}$, which was increased to 3.04 and $3.14 \mathrm{MPa}$ with the addition of 0.5 and $0.8 \%$ hazelnut shell biochar. The $1 \%$ biochar concrete had a strength of $2.73 \mathrm{MPa}$. Considering 7 days cured coffee powder biochar-added to cement, the biochar concrete strength was 2.12, 3.72, 3.4, and 2.8 for $0,0.5$, 0.8 , and $1 \%$ additions, respectively. The load vs. crack mouth opening displacement mode (CMOD) graph is shown in Figure 7c. This graph shows that the biochar-added concrete has a high peak load. It is understood that biochar is capable of altering the crack path. This is attributed to the biochar's strong interaction with cement, which aided the cement material in developing crack resistance. Furthermore, the increase in fracture energy can be explained by an increase in the toughness of the concrete. The addition of biochar created impenetrable obstacles that caused the modification of crack trajectory, leading to the increased fracture energy [93].

In another study, Restuccia and Ferro [95] found that using coarse-sized biochar particles improves the flexural strength of composites. In this study, hazelnut shell biochar with particle sizes of $140 \mu \mathrm{m}$ was used, and concrete was developed at $0.5,0.8$, and $1 \%$ concentrations. After seven days of curing, the maximum strength was recorded from the $0.5 \%$ concrete $(3.34 \mathrm{MPa})$, which was $51 \%$ higher than the reference concrete. The flexural strength of the $0.8 \%$ and $1 \%$ biochar concentrations were 2.72 and $2.65 \mathrm{MPa}$, respectively. By comparing the results of the investigation to the results of other investigations in the literature [96-98], the authors concluded that a coarser size of biochar at a lower percentage is sufficient to achieve higher mechanical strength. Due to the low density of the biochar, even at a lower percentage, the coarse-sized particles can fill the larger voids in the cement mixture, potentially increasing the strength. This finding is supported by the investigation of Ferro et al. [99]. This study used carbonised hemp hurds with an average particle size of $14 \mu \mathrm{m}$. The effect of biochar on the flexural strength of composites was investigated at four different proportions (i.e., $0.08,0.20,1.00$, and $3.00 \mathrm{wt} . \%$ biochar in cement). When $0.08 \%$ biochar was added to the cement, the modulus of rupture increased by $7 \%$. However, decrement was observed at 0.20, 1.00, and $3.00 \mathrm{wt} . \%$. The author also found that the addition of biochar particles increased the flexural toughness of the cement. According to the authors, the irregular-sized biochar particles had a significant impact on the crack paths by increasing their tortuosity.

Falliano et al. [100]. compared the flexural strength and fracture energy of the biochar concrete (foamed) composite with $2 \%$ and $4 \%$ of biochar and different curing mechanisms. The air-cured sample with no biochar showed the highest flexural strengths. The addition of $2 \%$ of biochar to the sample somewhat maintained the flexural strength, and the increment of the biochar content from $2 \%$ to $4 \%$ reduced the strength by $10 \%$. No significant difference was seen in the fracture energies between the control sample and the $4 \%$ biochar concrete composite, although there was about a $50 \%$ reduction for the $2 \%$ biochar water-cured sample. During the experiment, the samples were not perfectly aligned with the loading 
equipment. The reduction was, therefore, attributed to the sample orientation during the test which led to premature damage of the samples. In addition, the inclusion of biochar significantly reduced the compressive strength of the foamed concrete and worsened with any further increment.
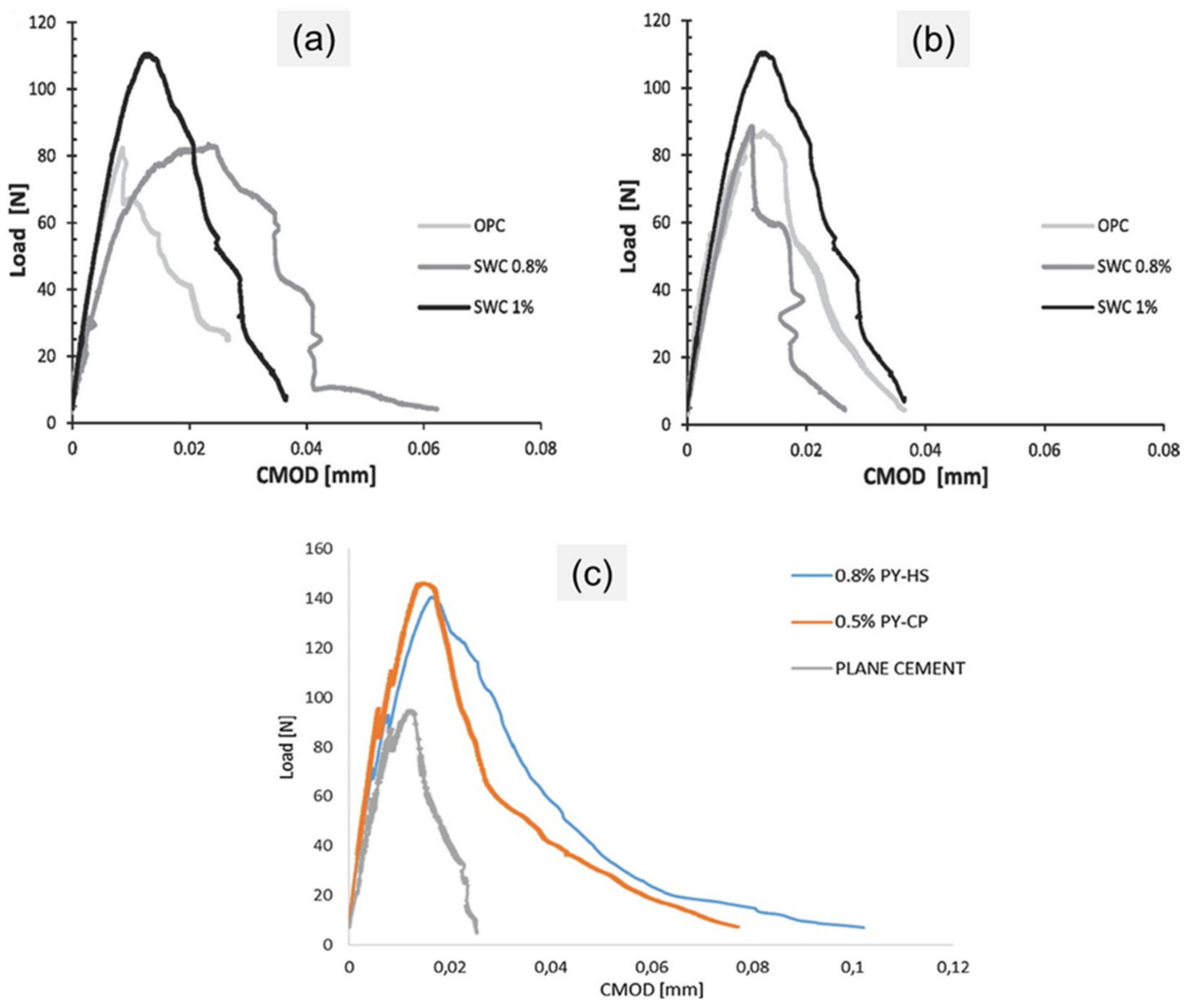

Figure 7. (a-c) Load vs. crack mouth opening displacement mode (CMOD) graph for biochar cement composites. (OPC, ordinary Portland cement; SWC, supplementary cementitious materials (biochar-added cementitious material); PY-HSpyrolysed hazelnut shells and PY-CP-pyrolysed coffee powder); Figure taken from Refs. [93,94].

Gupta et al. [90] also investigated the influence of the particle size of wood sawdust biochar on the flexural strength of cement mortar. Coarse biochar particles $(2 \mu \mathrm{m}-100 \mu \mathrm{m})$ and fine particles $(0.1 \mu \mathrm{m}-2 \mu \mathrm{m})$ at concentrations of $0.25 \%, 0.5 \%, 1 \%$, and $2 \%$ were mixed with cement and sand at a ratio of $1: 2.5 .0 .4 \mathrm{wt} \%$ of water was added to the mixture of dry components to prepare the concrete. In the case of flexural strength, the addition of $0.25 \%$ of fine biochar particles caused a reduction; however, further biochar increments to $1 \%$ resulted in a significant increase of up to $21 \%$. The $2 \mathrm{wt} \%$ of both fine and coarse biochar particles did not modify the flexural strength. It is worth noting that, based on the particle size, type, and preparation of biochar, different concentrations are required to optimise different mechanical properties. The concentration also affects the amount of water needed to improve the performance of concrete. Table 2 shows the flexural strength of the biochar-added cementitious materials. 
Table 2. Flexural strength reported on different biochar/cementitious materials.

\begin{tabular}{|c|c|c|c|c|c|c|c|c|}
\hline \multirow{2}{*}{ Construction Material } & \multirow{2}{*}{ Biochar Source } & \multirow{2}{*}{ Bio Content and Size } & \multirow{2}{*}{ Pyrolysis Conditions } & \multicolumn{5}{|c|}{ Flexural Strength (MPa) } \\
\hline & & & & 1 Day Curing & 7 Days Curing & 28 Days Curing & 30 Days Curing & 180 Days Curing \\
\hline $\begin{array}{c}\text { Ordinary Portland } \\
\text { Cement }\end{array}$ & Poultry litter [66] & $0.1 \%$ & $\begin{array}{l}\text { Slow pyrolysis at } 450^{\circ} \mathrm{C} \text { and } \\
\text { residence time is } 20 \mathrm{~min}\end{array}$ & - & - & $5^{*}$ & - & - \\
\hline $\begin{array}{c}\text { Ordinary Portland } \\
\text { Cement }\end{array}$ & $\begin{array}{l}\text { Pulp and Paper mill } \\
\text { biochar [66] }\end{array}$ & $0.1 \%$ & $\begin{array}{l}\text { Pyrolysis at } 500^{\circ} \mathrm{C} \text { using } \\
\text { high-temperature gasifier }\end{array}$ & - & - & $4^{*}$ & - & - \\
\hline $\begin{array}{c}\text { Ordinary Portland } \\
\text { Cement }\end{array}$ & Rice husk [66] & $0.1 \%$ & $\begin{array}{l}\text { Slow pyrolysis at } 500^{\circ} \mathrm{C} \text { and } \\
\text { residence time is } 20 \mathrm{~min}\end{array}$ & - & - & $5^{*}$ & - & - \\
\hline Cement Mortar & Mixed wood [89] & $1 \%$ and $5-200 \mu \mathrm{m}$ & $\begin{array}{l}\text { Pyrolysis at a temperature of } 500{ }^{\circ} \mathrm{C} \\
\text { and residence time is } 45-60 \mathrm{~min} . \\
\text { Heating rate is } 10^{\circ} \mathrm{C} / \mathrm{min}\end{array}$ & - & $11^{*}$ & $13^{*}$ & - & - \\
\hline Cement Mortar & Food waste [89] & $1 \%$ and $5-200 \mu \mathrm{m}$ & $\begin{array}{l}\text { Pyrolysis at a temperature of } 500{ }^{\circ} \mathrm{C} \\
\text { and residence time is } 45-60 \mathrm{~min} . \\
\text { Heating rate is } 10^{\circ} \mathrm{C} / \mathrm{min}\end{array}$ & - & $10^{*}$ & $13^{*}$ & - & - \\
\hline Cement Mortar & Rice waste [89] & $2 \%$ and 5-200 $\mu \mathrm{m}$ & $\begin{array}{l}\text { Pyrolysis at a temperature of } 500{ }^{\circ} \mathrm{C} \\
\text { and residence time is } 45-60 \mathrm{~min} . \\
\text { Heating rate is } 10^{\circ} \mathrm{C} / \mathrm{min}\end{array}$ & - & $9 *$ & $11^{*}$ & - & - \\
\hline Cement Mortar & Sawdust [90] & $1 \%$ and $0.92-100 \mu \mathrm{m}$ & $\begin{array}{l}\text { Pyrolysis temperature is } 500^{\circ} \mathrm{C} \text { and } \\
\text { heating rate is } 10^{\circ} \mathrm{C} / \mathrm{min}\end{array}$ & - & - & $\begin{array}{l}11 \text { (moist curing) } \\
10 \text { (air curing) }\end{array}$ & - & - \\
\hline $\begin{array}{l}\text { Magnesium Phosphate } \\
\text { Cement }\end{array}$ & Wheat straw [71] & $1.5 \%$ and $2.05 \mu \mathrm{m}$ & $\begin{array}{l}\text { Pyrolysis temperature at } 6500^{\circ} \mathrm{C} \text { and } \\
\text { at a heating rate of } 188^{\circ} \mathrm{C} / \mathrm{min}\end{array}$ & $10^{*}$ & - & - & $12 *$ & $13 *$ \\
\hline $\begin{array}{l}\text { Ordinary Portland } \\
\text { Cement }\end{array}$ & $\begin{array}{c}\text { Chemically treated, } \\
\text { Pyrolysed and annealed } \\
\text { bamboo [78] }\end{array}$ & $0.08 \%$ and $1-2 \mu \mathrm{m}$ & $\begin{array}{l}\text { Pyrolysis temperature is } 850^{\circ} \mathrm{C} \text { and } \\
\text { at a heating rate of } 1^{\circ} \mathrm{C} / \mathrm{min}\end{array}$ & - & - & $4^{*}$ & - & - \\
\hline Ordinary cement & Shellfish biowaste [92] & $0.1 \%$ & $\begin{array}{l}\text { Pyrolysis temperature is } 800^{\circ} \mathrm{C} \text { and } \\
\text { at a heating rate of } 5{ }^{\circ} \mathrm{C} / \mathrm{min}\end{array}$ & 2 & - & - & - & - \\
\hline Cement mortar & Mixed sawdust [75] & $2 \mathrm{wt} \%$ and $5-500 \mu \mathrm{m}$ & $\begin{array}{c}\text { Pyrolysis between } 300-500{ }^{\circ} \mathrm{C} \text { and at } \\
\text { a heating rate of } 10^{\circ} \mathrm{C} / \mathrm{min}\end{array}$ & - & - & $\begin{array}{l}\text { Moist curing-13* } \\
\text { Air curing-11* }\end{array}$ & - & - \\
\hline Cement Mortar & Wood chips [80] & $1 \mathrm{wt} \%$ and $38 \mu \mathrm{m}$ & $\begin{array}{l}\text { Pyrolysis temperature is between } 200 \\
\text { and } 500^{\circ} \mathrm{C} \text { and gasification } \\
\text { temperature is } 900^{\circ} \mathrm{C}\end{array}$ & - & $5^{*}$ & $6^{*}$ & - & - \\
\hline
\end{tabular}

*-Values with star are taken from the graph (rounded). 


\subsubsection{Tensile Strength}

Portland cement-based concrete materials have good compressive strength, but their tensile strength is very low due to their quasi-brittle nature. Cracks in the cement structure may form as a result of factors such as stress concentration, drying, and shrinkage, which may increase under loading [101]. As a result, microcracks may develop into macro cracks or become connected to the adjacent microcracks, forming branches and resulting in failure. Another important consideration is the brittleness of the concrete materials, which has a direct impact on the tensile strength of the cement. According to various published research work, the addition of micro reinforcements such as fibre reinforcements can control crack growth in cement materials [102-108]. Biochar could be used as an efficient particle reinforcement to increase the tensile strength of cement. There were only a few articles in the research of cementitious materials that discussed the tensile properties.

Qin et al. [109] developed pervious concrete by incorporating $0 \mathrm{wt.} \%, 0.65 \mathrm{wt} . \%$, $3.2 \mathrm{wt.} \%, 6.5 \mathrm{wt} . \%, 9.5 \mathrm{wt} . \%$, and $13.5 \mathrm{wt.} \%$ pyrolysed biochar from eucalyptus plywood boards. The splitting tensile strength of $0.65 \mathrm{wt}$.\% biochar-added concrete was significantly improved. When compared to the reference, the biochar-added concretes showed an increasing trend in tensile strength; however, after $3.2 \%$ addition, a decrement was observed on the 28-day cured biochar concrete, whereas for 7 days cured concrete, a decrement was noted for $0.65 \mathrm{wt} . \%$ biochar addition. When compared to reference concrete, $0.65 \mathrm{wt} . \%$ biochar-added concrete ( 7 days cured) showed a $23 \%$ increase in tensile strength, while $3.2 \mathrm{wt}$ \% biochar-added concrete ( 28 days cured) exhibited a $24 \%$ increase. This increase was caused by biochar's physical and chemical interaction with cement and its aggregates. The authors observed that the biochar concrete contained a high concentration of calcium carbonate $\left(\mathrm{CaCO}_{3}\right)$ and calcium hydroxide $\left(\mathrm{Ca}(\mathrm{OH})_{2}\right)$. This demonstrates the role of biochar in cement hydration. The biochar accelerated cement hydration, resulting in the formation of hydration products such as $\mathrm{Ca}(\mathrm{OH})_{2}$ and $\mathrm{C}-\mathrm{S}-\mathrm{H}$. This was also attributed to biochar's larger specific surface area and smaller particle size. Due to the biochar's filler effect, the smaller size of biochar, compared to the other elements in cement, aided in filling the pores. This resulted in improved load distribution thereby increasing the strength. However, high percentages of biochar addition resulted in agglomeration and reduced the strength. According to Gupta et al. [110], the inhomogeneity of biochar is high, in comparison to the cementitious matrix, resulting in a weaker interface (Figure 8) with the cementitious matrix. Furthermore, increased biochar content may result in the formation of a weaker interfacial zone, resulting in lower tensile strength. However, an investigation by Zeidabadi et al. [77] reported maximum tensile strength on the $5 \mathrm{wt} . \%$ and $10 \mathrm{wt} . \%$ (by mass of cement) biochar used as cement replacement in concretes. A maximum increase of approximately $70 \%$ was observed for the $5 \mathrm{wt} . \%$ bagasse biochar. The increased interfacial zone in the biochar was primarily responsible for the increased strength. In this study, enhanced interfacial adhesion was achieved by pre-treatment of the biochar feedstock. Pre-treatment was carried out by treating the biochar on $0.1 \mathrm{~N} \mathrm{HCl}$ solution.

Akhtar and Sarmah [111] investigated the effect of biochar on recycled aggregate concrete. Rice husk biochar and poultry litter biochar were used in this study. Biochar was added to cement in amounts of $0.1 \%, 0.25 \%, 0.5 \%$, and $0.75 \%$ of the total volume of cement. Both biochar-added concretes showed no increase in strength after 7, 14, and 28 days of curing. When compared to the control, all of the samples showed $16 \%$ lower strength, notably, $0.1 \%$ addition of poultry litter biochar showed an $8 \%$ reduction in strength. It is worth noting that when the curing time was increased, all of the composites showed increased strength. This finding implies that long-term curing is effective for recycled aggregate concrete which may lead to increased strength. However, detailed critical research in this area is required to justify this conclusion. 


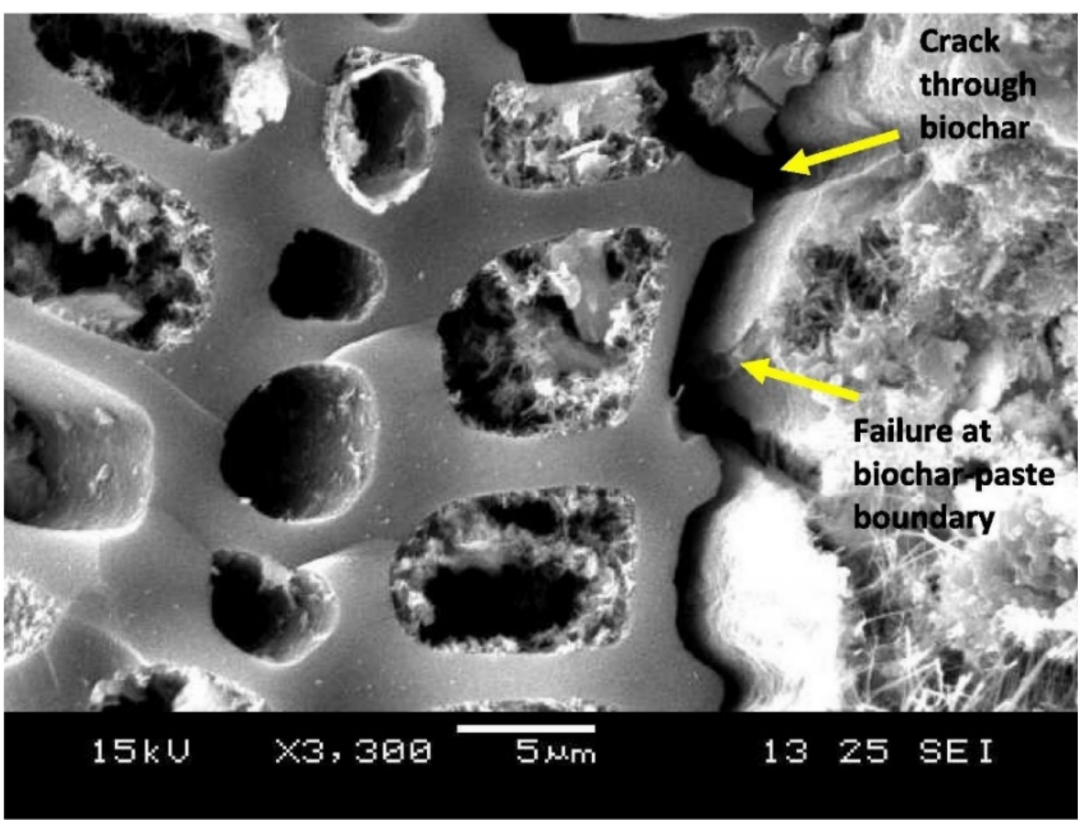

Figure 8. Microcrack in the cement matrix interface zone [110].

\subsection{Thermal Behaviour of Biochar/Cementitious Material}

Concrete with no chemical agents releases few or no flammable volatiles; hence, it does not necessarily contribute to fire hazards. However, exposing concrete to elevated temperatures causes it to dehydrate [112], expand, crack, or break and lose its structural integrity [113]. Concrete has a relatively low thermal conductivity that slows down any reaction to fire and flames. High-temperature biochar is fire resistant and has high thermal stability [54]. In this section, the changes observed in the thermal properties of concrete with the addition of biochar are reviewed. Gupta et al. [114] subjected concrete and biocharadded concrete to elevated temperatures $\left(300^{\circ} \mathrm{C}\right.$ and $\left.550{ }^{\circ} \mathrm{C}\right)$ in order to evaluate the effect on mass loss, mechanical properties, and permeability. The feedstock for the preparation of the biochar was mixed wood sawdust, and the concentrations were maintained at $0.5 \%, 1 \%$, and $2 \%$ of the cement weight. It was observed that the mass loss rate of both samples at $550{ }^{\circ} \mathrm{C}$ was higher than $300^{\circ} \mathrm{C}$. Dehydration and the decomposition of binder gel, as well as calcium silicate hydrate, occur at $300^{\circ} \mathrm{C}$; hence, at this temperature, the samples exhibited similar mass loss $(3-3.2 \%)$. At $550{ }^{\circ} \mathrm{C}$, the addition of biochar resulted in a significant reduction in mass loss, compared to the reference concrete, and further increments in biochar content enhanced the thermal stability. It was realised that increasing the biochar content led to an increase in the number of pores in the mix, allowing the release of built-up pressure at elevated temperatures. This, in turn, reduced the internal damage and maintained the structural integrity. However, the plain concrete experienced microcracking which caused spalling.

Cuthbertson et al. [115] analysed the thermal conductivity and thermal resistance of biochar concrete with different loading amounts of biochar $(1 \%, 5 \%, 10 \%$, and $12 \%)$ as replacements to aggregate and sand with varying cement/water (C-W) ratios. The research showed that the sample having a 0.67 cement-water ratio, and $5 \%$ biochar/sand replacement displayed the highest thermal conductivity and consequently the lowest thermal resistance. A critical observation made in this analysis was that the samples had low thermal conductivities at lower temperature ranges indicating a reduction in the insulation capabilities of biochar concrete in colder regions. The thermal resistance and conductivities of the samples used for the research are shown in Figure 9. 


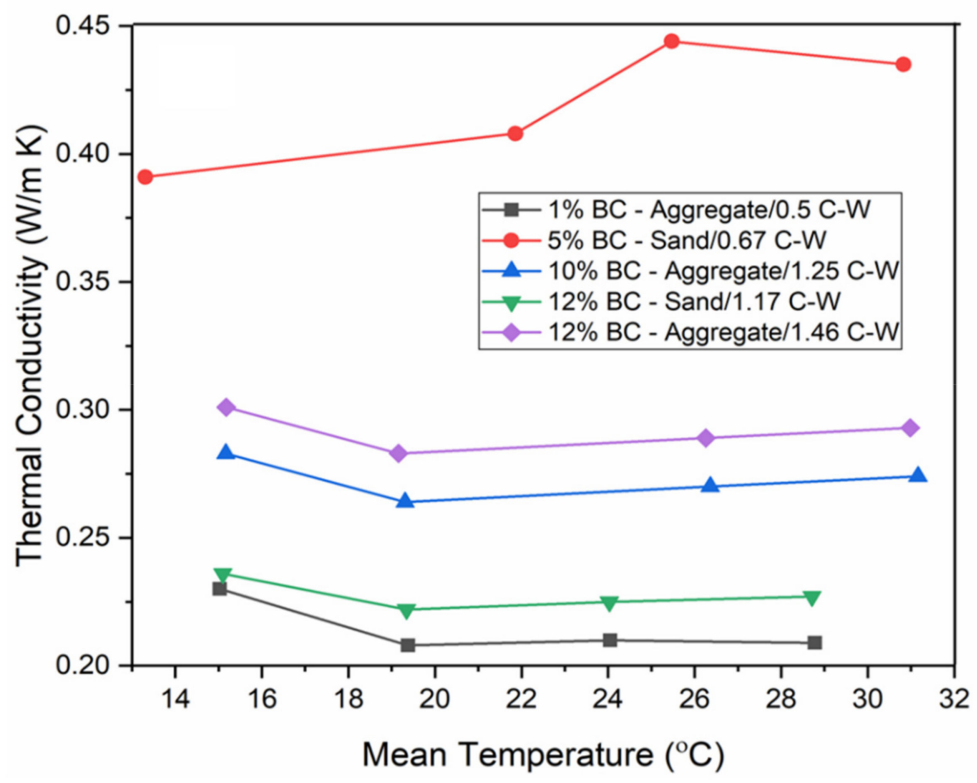

Figure 9. Thermal conductivity of biochar added concrete [115].

Yang et al. [116] created a composite building material by combining red clay and biochar. Although red clay is not a cementitious material, the effect of biochar on the thermal property of a clay-type material can be understood. The biochar used in the study was made from the pyrolysis of rice husk, coconut shell, and bamboo. Biochar was mixed with the red clay in four different proportions $(2.5,5,7.5$, and $10 \mathrm{wt} . \%)$. Among the three biochars used, rice husk biochar with red clay had the lowest conductivity, ranging from $0.123 \mathrm{~W} / \mathrm{m} \mathrm{K}$ to $0.184 \mathrm{~W} / \mathrm{m} \mathrm{K}$. The $5 \%$ coconut shell biochar and red clay had the highest thermal conductivity of $0.231 \mathrm{~W} / \mathrm{m} \mathrm{K}$, which was $5 \%$ lower than the red clay without any biochar $(0.244 \mathrm{~W} / \mathrm{m} \mathrm{K})$. The rice husk biochar-added red clay had the lowest thermal conductivity due to the material's voids and pores. However, in order to understand the conductivity property in biochar-added building materials, the mixing ratio of the biochar must be optimised. It is also critical to investigate the dynamic heat transfer in biochar-added building materials. Biochar was found to have lower heat reactivity in a dynamic heat transfer analysis [117]. This can be attributed to the biochar-added cement's lower thermal conductivity.

Similar to Yang et al. [116], Tan et al. [118] also reported the porosity of biochar as the main reason for the reduced thermal conductivity in the biochar-added mortar developed using waste wood as feedstock. Biochar was created using four different pyrolysis temperatures: $400{ }^{\circ} \mathrm{C}, 500{ }^{\circ} \mathrm{C}, 600^{\circ} \mathrm{C}$, and $700^{\circ} \mathrm{C}$. The biochar-added mortar was developed at five varying proportions $(0,1,3,5$, and $10 \mathrm{wt} . \%)$ and added to the cement before mixing with sand and water. The biochar addition reduced the thermal conductivity of the mortar. For example, when compared to the reference mortar, the addition of 1 , 3,5 , and $10 \mathrm{wt} \%$ biochar pyrolysed at $400{ }^{\circ} \mathrm{C}$ reduced the thermal conductivity by $16 \%$, $22 \%, 30 \%$, and $39 \%$, respectively. The author compared the thermal conductivity and porosity results, interestingly both followed similar trends. It was determined that the high porosity of biochar created by the release of volatiles was the principal cause of the reduced thermal conductivity. Furthermore, increasing the biochar weight percentage decreased the thermal conductivity in all cases. Considering the results of these two investigations, it is possible to conclude that biochar can be an effective thermal insulation material for cementitious applications.

Wu et al. [32] described the mechanism underlying the biochar-added concrete's thermal insulation using Figure 10, based on the experimental results. The highly porous biochar in the concrete acts as a thermal insulator, preventing heat transfer within the matrix. Normal biochar has poor interfacial adhesion with the cement matrix when compared to heat-treated biochar. As a result, heat cannot pass through the poor interfacial 
region in normal biochar, resulting in lower thermal conductivity than heat-treated biochar. However, in the heat-treated biochar, heat can be transferred via interfacial adhesion, thus increasing the thermal conductivity. The absence of thermally insulating material (i.e., biochar) in the reference concrete caused direct heat transfer within the matrix, resulting in increased thermal conductivity. Thus, the thermal diffusivity of the normal peach shell and apricot shell biochar-added concrete was 0.40 and $0.34 \times 10^{-6} \mathrm{~m}^{2} / \mathrm{s}$, respectively, while it was 0.70 and $0.55 \times 10^{-6} \mathrm{~m}^{2} / \mathrm{s}$ for the heat-treated peach shell and apricot shell biochar-added concrete [32]. Thus, it was understood that heat transfer in reference mortar occurs through the matrix, the aggregate, and the interfacial zone, while heat transfer in normal biochar-added concrete occurs only through the matrix. Additionally, heat transfer in heat-treated biochar occurs through the matrix and the interfacial zone.

(a) Normal weight concrete

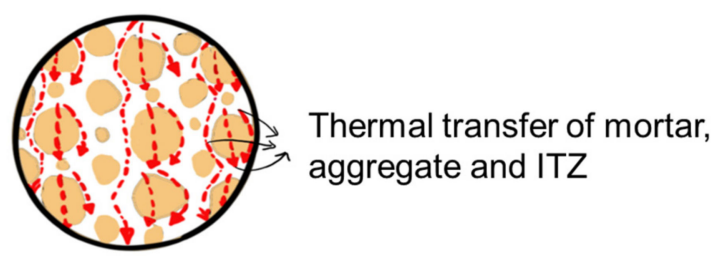

(b) Untreated bio-aggregate concrete

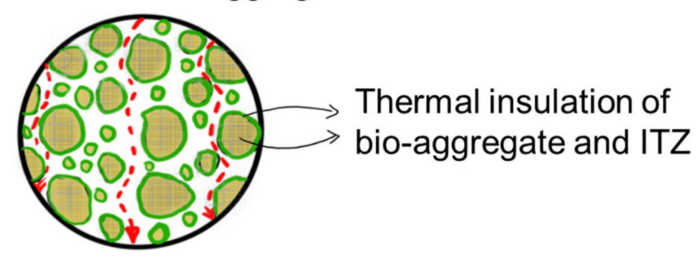

(c) Heat-treated bio-aggregate concrete

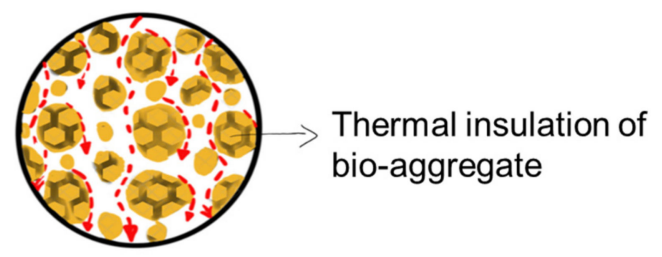

Figure 10. Thermal insulation mechanism of bio-based concrete (ITZ $=$ interfacial transition zone) [32].

It has been quite clearly shown in this review that the addition of biochar to concrete improves the thermal insulation property; however, further increments of the concentration of biochar do not necessarily result in improved thermal properties. This phenomenon could be attributed to the increased density in connection with the addition of biochar, which reduces thermal resistance. Nevertheless, the utilisation of biochar/concrete can significantly enhance the thermal properties of energy-efficient buildings.

\section{Life Cycle Assessment (LCA) of Biochar/Concrete}

Biochar has the capability for enhancing the mechanical properties of concrete and decreasing the amount of cement, hence reducing the amount of $\mathrm{CO}_{2}$ emitted in concrete manufacturing. Due to this, it has a great potential of becoming the centrepiece of construction. In order to commercialise the addition of biochar to concrete, it is imperative to conduct a life cycle assessment (LCA) to avoid any possible implications on the environment. LCA is a method used to determine the effect of the stages of a product's life, from manufacturing to end of life, on the environment $[119,120]$. The LCA technique comprises four key procedures, specifically cradle-to-gate, cradle-to-grave, cradle-to-cradle, and life cycle energy analyses. The cradle-to-grave analysis assesses the life cycle of the product 
in its entirety. The cradle-to-gate analysis focuses on the extraction of raw materials to processes occurring at the factory. The cradle-to-cradle analysis evaluates the recyclability of the product and life cycle energy analysis deals with the energy required from manufacturing of a product to disposal [121,122]. The assessment of the environmental impacts of biochar and concrete mixture using these techniques is discussed in this section.

The cradle-to-gate analytical method was used by Campos et al. [122] to assess the impact of the raw material acquisition process, material processing, production, and transportation of rice husk biochar/concrete materials on the environment. The loading amounts of biochar ranged from $0 \mathrm{wt} . \%$ to $20 \mathrm{wt} . \%$ and the cement content was $0.19 \mathrm{~kg}$ to $0.15 \mathrm{~kg}$. It was observed in the analysis that increasing the amount of biochar minimised ozone depletion, toxicity (in air, water, soil), and hazardous waste and improved ozone formation. The impacts on other categories such as global warming, acidification, terrestrial and aquatic eutrophication were also significantly lowered. The authors proposed the use of biochar as a replacement to fly ash due to excellent results from the study.

Gupta et al. [4] conducted an extensive study on the utilisation of biochar derived from mixed wood sawdust as a carbon-capturing admixture in concrete. A section of the biochar was saturated with $\mathrm{CO}_{2}$ and added to the concrete. The effect of the saturated and unsaturated biochar on the emission of greenhouse gases and global warming potential was analysed in the study. The results showed that the application of biochar reduced $\mathrm{CO}_{2}$ emissions and lowered the release of methane, $\mathrm{NO}_{\mathrm{x}}$, and $\mathrm{SO}_{\mathrm{x}}$ during production. The net global warming potential for the concrete with no biochar was $7.8 \mathrm{kgCO}_{2}$-eq, while $6.65 \mathrm{kgCO}_{2}$-eq and $6.63 \mathrm{kgCO}_{2}$-eq were recorded for saturated and unsaturated biochar/concrete mixes, respectively. These estimations affirm the ability of biochar to reduce the environmental impacts of concrete. In another work, the same authors used waste peanut shell biochar to improve the properties of cement mortar, as well as cement and fly ash mortar. Substituting 3\% of cement with biochar significantly reduced the $\mathrm{CO}_{2}$ emission [123]. Tommaso et al. [124] realised that adding $1 \%$ of biochar-based activated carbon to high-performance concrete could reduce the $\mathrm{CO}_{2}$ emission by $0.5 \mathrm{Gt}$. In addition, Suarez et al. [125] stated that the replacement of $2 \%$ of cement with biochar in a $1 \mathrm{~m}^{3}$ cement paste production leads to a reduction of $67 \mathrm{~kg}$ of atmospheric $\mathrm{CO} 2$. Activated charcoals and carbons are effective industrial adsorbents, and the incorporation of such materials in fresh concrete resulted in increased $\mathrm{NO}_{2}$ absorption by the hardened product [126-128]. In this manner, it is anticipated that the addition of biochar to cement could contribute to the absorption of $\mathrm{NO}_{\mathrm{x}}$, thereby greatly reducing the environmental impact; however, research in this area is limited. The LCA analysis reviewed proves that the inclusion of biochar in concrete presents an environmentally safe alternative in the construction industry; therefore, its implementation will alleviate the global warming issues at hand.

\section{Economic Benefits}

The cost of biochar is dependent on the type, quality of feedstock, and production scale. Huang et al. [129] conducted an economic analysis on the production of biochar from poultry litter waste. The authors found out that the cost of producing a tonne of poultry litter biochar is USD 266. Incorporating the sale of electricity and heat further reduced the cost to USD 217. However, the market price of biochar is USD 184 per tonne. Shackley et al. [130] went a step further to add the transportation and application costs of biochar. It was realised that the price per tonne ranged from USD 222 to USD 584, depending on the pyrolysis scale and the quantity of feedstock consumed.

Akhtar et al. [66] mixed concrete with biochar content equivalent to a range of $0.1-1 \%$ of the total volume of concrete. The feedstocks for the experiments were rice husk (RH), pulp and paper mill, and poultry litter. The authors analysed the production cost of medium-scale biochar concrete and compared it to that of conventional concrete. A cost reduction of about USD1 for every $0.25 \%$ increment was noted. Hence, increasing the content of biochar decreased the production cost. However, the reduction was insignificant due to 
the addition of small amounts of biochar. The authors suggested that the commercialisation of biochar concrete with large-scale production could yield significant economic gains.

\section{Fire Properties}

Studies on the fire performance of concrete have shown that, compared to building materials such as steel and wool, concrete demonstrates the best fire resistance [131]. The addition of reinforcements further increases the thermal stability of the concrete. However, according to previous research, the size and form of the reinforcements may not have a significant influence on thermal stability [132]. In addition, reinforced concrete exhibits an increase in strength to a certain temperature of ca. $450{ }^{\circ} \mathrm{C}$ and decreases as the temperature is elevated beyond $600{ }^{\circ} \mathrm{C}$ [133]. There is a dearth of studies regarding the fire behaviour of concrete structures that have biochar. Due to the strong $\mathrm{C}-\mathrm{C}$ covalent bonds in biochar that are produced at high temperatures (ca. $>700{ }^{\circ} \mathrm{C}$ ), it is envisaged that their addition to concrete can be beneficial. Fire damage in concrete mainly occurs through two mechanisms. Firstly, when the temperature rises slowly, the moisture present in the concrete pores moves away from the hot face of the structure leading to dehydration of the concrete paste. This compromises the bond between the paste and the aggregate, adversely affecting the structural integrity as the layers fall off. Secondly, as the temperature rises fast, the moisture rapidly expands instead of travelling away from the heat source, leading to a pressure increase. The high pressure creates stress that supersedes the tensile strength of the concrete structure resulting in violent spalling. To mitigate these issues, biochar can be used to either replace some of the aggregate or the cement. This forms a platform for future research into this area. Rendering concrete structures fire resistant, mainly in mines and tunnels, is of utmost importance to safeguard the lives of humans and reduce the destruction of properties. Additionally, low-carbon emission materials are gaining attention $[134,135]$ as a means to reduce greenhouse gas emissions from the manufacturing of construction materials. Hence, increasing the sustainability of construction structures using bio-based resources (e.g., biochar) is paramount to ensure a sustainable future [136].

\section{Conclusions}

This review provides information about the thermal and mechanical properties of biochar and biochar-added cementitious materials. In comparison to ash and other biobased constituents, biochar has a high potential as an additive material in cement. Most importantly, converting biomass to biochar would aid in carbon sequestration and lowering the possibility of greenhouse gas emissions. The inclusion of a small amount of biochar in cement is expected to result in a greater reduction in greenhouse gas emissions. No significant reduction in the production cost of biochar-added concrete was observed in small-scale productions; however, it is anticipated that large-scale manufacturing could yield some economic benefits.

It is worth noting that biochar produced at high temperatures has a high heat resistance due to $\mathrm{C}-\mathrm{C}$ covalent bonding. This helps to improve flammability resistance because, at high-temperature pyrolysis, the volatiles evolve, leaving only the crosslinked carbon skeleton. The porous nature of the biochar is extremely beneficial in terms of improving mechanical interlocking with the cement matrix as well as lowering thermal conductivity. It is clear that inherent biochar properties are critical in the development of biochar-added cementitious materials. Similar pyrolysis conditions cannot be expected to provide the same properties in biochar because it is highly dependent on the type of feedstock material. This led to the conclusion that the property of the biochar-added cement is a factor of biochar properties and the biochar feedstock material.

It was realised in the study that the variation in mechanical and thermal characteristics of biochar concrete depended on the biochar loading amount. The percentage of biochar loaded depends on the feedstock type and particle size. In this case, more research and optimised conditions are required for improvement. However, coarse-sized particles at a 
lower content are recommended, as the particles fill the larger voids in the concrete mixture, thereby increasing the strength.

Most of the studies conducted regarding the use of biochar in concrete used very low loading amounts. In order to contribute to sustainability and reduce carbon footprint, higher biochar content should be used. However, there is a dearth of studies that applied high amounts of biochar in concrete, thus opening up new avenues for future research. Despite the documented positive effect of biochar in concrete, industries have not yet adopted it as an additive. This is because of the lack of knowledge regarding the potential of biochar, which can be ameliorated through the dissipation of this article. People in concrete industries might still think that biochar is mainly for soil-based applications and this dated notion must be updated through research outcomes and effective dispersion of those results in the public domain to overcome the market entry barriers. Nevertheless, it is to be kept in mind that biochar addition in concrete can have some unintended consequences. Biochar (or other porous carbons) with a high surface area has the ability to absorb or retain water. Hence, on the one hand, this very ability will aid in the hydration of cement but on the other hand, as shown by Horgnies et al. [126], this might affect the watercement ratio, thereby lowering its workability, although not significantly. Additionally, the efficacy of chemical admixtures might alter in a biochar/concrete system because they might be adsorbed inside the pores of the biochar. This warrants future studies to observe if the efficacy of chemical admixtures reduces in the presence of biochar.

Author Contributions: Conceptualisation, O.D.; methodology, O.D. and G.S.; validation, V.S., R.A.M., S.M.J.R., and F.S.; formal analysis, O.D., V.S., R.A.M., S.M.J.R., M.F., T.B., and P.S.; investigation, V.S., S.N., R.A.M., O.D., B.R.; resources, G.S.; data curation, V.S., R.A.M., S.N.; writing-original draft preparation, V.S. and R.A.M.; writing—review and editing, O.D., S.M.J.R., A.U., D.S. and G.S.; supervision, O.D., G.S., M.F., and S.M.J.R.; project administration, G.S. and O.D. All authors have read and agreed to the published version of the manuscript.

Funding: This research received no external funding.

Institutional Review Board Statement: Not applicable.

Informed Consent Statement: Not applicable.

Data Availability Statement: Not applicable.

Conflicts of Interest: The authors declare no conflict of interest.

\section{References}

1. The Warming Effects of the Industrial Revolution-Global Temperatures. Available online: https:/ /www.climate-policy-watcher. org/global-temperatures/the-warming-effects-of-the-industrial-revolution.html (accessed on 31 May 2021).

2. Climate Change: Atmospheric Carbon Dioxide I NOAA Climate.gov. Available online: https:/ /www.climate.gov/news-features / understanding-climate/climate-change-atmospheric-carbon-dioxide (accessed on 31 May 2021).

3. Lüthi, D.; Le Floch, M.; Bereiter, B.; Blunier, T.; Barnola, J.M.; Siegenthaler, U.; Raynaud, D.; Jouzel, J.; Fischer, H.; Kawamura, K.; et al. High-resolution carbon dioxide concentration record 650,000-800,000 years before present. Nature 2008, 453, 379-382. [CrossRef] [PubMed]

4. Gupta, S.; Kua, H.W.; Low, C.Y. Use of biochar as carbon sequestering additive in cement mortar. Cem. Concr. Compos. 2018, 87, 110-129. [CrossRef]

5. Worrell, E.; Price, L.; Martin, N.; Hendriks, C.; Meida, L.O. Carbon dioxide emissions from the global cement industry. Annu. Rev. Energy Environ. 2001, 26, 303-329. [CrossRef]

6. Oh, D.Y.; Noguchi, T.; Kitagaki, R.; Park, W.J. $\mathrm{CO}_{2}$ emission reduction by reuse of building material waste in the Japanese cement industry. Renew. Sustain. Energy Rev. 2014, 38, 796-810. [CrossRef]

7. Global Cement Industry CO2 Emissions 2019/Statista. Available online: https://www.statista.com/statistics/1091672/carbondioxide-emissions-global-cement-manufacturing/ (accessed on 31 May 2021).

8. Naqi, A.; Jang, J.G. Recent progress in green cement technology utilizing low-carbon emission fuels and raw materials: A review. Sustainability 2019, 11, 537. [CrossRef]

9. Feiz, R.; Ammenberg, J.; Baas, L.; Eklund, M.; Helgstrand, A.; Marshall, R. Improving the $\mathrm{CO}_{2}$ performance of cement, part I: Utilizing life-cycle assessment and key performance indicators to assess development within the cement industry. J. Clean. Prod. 2015, 98, 272-281. [CrossRef] 
10. Boesch, M.E.; Hellweg, S. Identifying improvement potentials in cement production with life cycle assessment. Environ. Sci. Technol. 2010, 44, 9143-9149. [CrossRef] [PubMed]

11. Ammenberg, J.; Baas, L.; Eklund, M.; Feiz, R.; Helgstrand, A.; Marshall, R. Improving the $\mathrm{CO}_{2}$ performance of cement, part III: The relevance of industrial symbiosis and how to measure its impact. J. Clean. Prod. 2015, 98, 145-155. [CrossRef]

12. Miller, S.A.; John, V.M.; Pacca, S.A.; Horvath, A. Carbon dioxide reduction potential in the global cement industry by 2050. Cem. Concr. Res. 2018, 114, 115-124. [CrossRef]

13. Zhang, J.; Liu, G.; Chen, B.; Song, D.; Qi, J.; Liu, X. Analysis of $\mathrm{CO}_{2}$ Emission for the cement manufacturing with alternative raw materials: A LCA-based framework. Energy Procedia 2014, 61, 2541-2545. [CrossRef]

14. Hossain, M.U.; Poon, C.S.; Lo, I.M.C.; Cheng, J.C.P. Comparative LCA on using waste materials in the cement industry: A Hong Kong case study. Resour. Conserv. Recycl. 2017, 120, 199-208. [CrossRef]

15. Manjunatha, M.; Preethi, S.; Mounika, H.G.; Niveditha, K.N. Ravi Life cycle assessment (LCA) of concrete prepared with sustainable cement-based materials. Mater. Today Proc. 2021. [CrossRef]

16. Boix, E.; Gineau, E.; Narciso, J.O.; Höfte, H.; Mouille, G.; Navard, P. Influence of chemical treatments of miscanthus stem fragments on polysaccharide release in the presence of cement and on the mechanical properties of bio-based concrete materials. Cem. Concr. Compos. 2020, 105, 103429. [CrossRef]

17. Chennouf, N.; Agoudjil, B.; Alioua, T.; Boudenne, A.; Benzarti, K. Experimental investigation on hygrothermal performance of a bio-based wall made of cement mortar filled with date palm fibers. Energy Build. 2019, 202, 109413. [CrossRef]

18. van der Bergh, J.M.; Miljević, B.; Šovljanski, O.; Vučetić, S.; Markov, S.; Ranogajec, J.; Bras, A. Preliminary approach to bio-based surface healing of structural repair cement mortars. Constr. Build. Mater. 2020, 248, 118557. [CrossRef]

19. Sierra-Beltran, M.G.; Jonkers, H.M.; Schlangen, E. Characterization of sustainable bio-based mortar for concrete repair. Constr. Build. Mater. 2014, 67, 344-352. [CrossRef]

20. Williams, S.L.; Kirisits, M.J.; Ferron, R.D. Optimization of growth medium for Sporosarcina pasteurii in bio-based cement pastes to mitigate delay in hydration kinetics. J. Ind. Microbiol. Biotechnol. 2016, 43, 567-575. [CrossRef] [PubMed]

21. Lamas, W.D.Q.; Palau, J.C.F.; De Camargo, J.R. Waste materials co-processing in cement industry: Ecological efficiency of waste reuse. Renew. Sustain. Energy Rev. 2013, 19, 200-207. [CrossRef]

22. Li, X.D.; Poon, C.S.; Sun, H.; Lo, I.M.C.; Kirk, D.W. Heavy metal speciation and leaching behaviors in cement based solidified/stabilized waste materials. J. Hazard. Mater. 2001, 82, 215-230. [CrossRef]

23. Hossain, N.; Bhuiyan, M.A.; Pramanik, B.K.; Nizamuddin, S.; Griffin, G. Waste materials for wastewater treatment and waste adsorbents for biofuel and cement supplement applications: A critical review. J. Clean. Prod. 2020, 255, 120261. [CrossRef]

24. He, Z.; Shen, A.; Wu, H.; Wang, W.; Wang, L.; Yao, C.; Wu, J. Research progress on recycled clay brick waste as an alternative to cement for sustainable construction materials. Constr. Build. Mater. 2021, 274, 122113. [CrossRef]

25. Chore, H.S.; Joshi, M.P. Strength characterization of concrete using industrial waste as cement replacing materials for rigid pavement. Innov. Infrastruct. Solut. 2020, 5, 1-9. [CrossRef]

26. Rattanachu, P.; Toolkasikorn, P.; Tangchirapat, W.; Chindaprasirt, P.; Jaturapitakkul, C. Performance of recycled aggregate concrete with rice husk ash as cement binder. Cem. Concr. Compos. 2020, 108, 103533. [CrossRef]

27. Hu, L.; He, Z.; Zhang, S. Sustainable use of rice husk ash in cement-based materials: Environmental evaluation and performance improvement. J. Clean. Prod. 2020, 264, 121744. [CrossRef]

28. Islam, M.S.; Elahi, T.E.; Shahriar, A.R.; Mumtaz, N. Effectiveness of fly ash and cement for compressed stabilized earth block construction. Constr. Build. Mater. 2020, 255, 119392. [CrossRef]

29. Liang, S.; Chen, J.; Guo, M.; Feng, D.; Liu, L.; Qi, T. Utilization of pretreated municipal solid waste incineration fly ash for cement-stabilized soil. Waste Manag. 2020, 105, 425-432. [CrossRef]

30. Akinyemi, B.A.; Dai, C. Development of banana fibers and wood bottom ash modified cement mortars. Constr. Build. Mater. 2020, 241, 118041. [CrossRef]

31. Carević, I.; Baričević, A.; Štirmer, N.; Šantek Bajto, J. Correlation between physical and chemical properties of wood biomass ash and cement composites performances. Constr. Build. Mater. 2020, 256, 119450. [CrossRef]

32. Wu, F.; Yu, Q.; Liu, C. Durability of thermal insulating bio-based lightweight concrete: Understanding of heat treatment on bio-aggregates. Constr. Build. Mater. 2021, 269, 121800. [CrossRef]

33. Wei, J.; Meyer, C. Degradation mechanisms of natural fiber in the matrix of cement composites. Cem. Concr. Res. 2015, 73, 1-16. [CrossRef]

34. Singh, H.; Gupta, R. Influence of cellulose fiber addition on self-healing and water permeability of concrete. Case Stud. Constr. Mater. 2020, 12, e00324. [CrossRef]

35. Ou, Z.H.; Ma, B.G.; Jian, S.W. Influence of cellulose ethers molecular parameters on hydration kinetics of Portland cement at early ages. Constr. Build. Mater. 2012, 33, 78-83. [CrossRef]

36. Chandrasekhar, S.; Pramada, P.N.; Majeed, J. Effect of calcination temperature and heating rate on the optical properties and reactivity of rice husk ash. J. Mater. Sci. 2006, 41, 7926-7933. [CrossRef]

37. Ramamurthy, K.; Harikrishnan, K.I. Influence of binders on properties of sintered fly ash aggregate. Cem. Concr. Compos. 2006, 28, 33-38. [CrossRef]

38. Das, O.; Sarmah, A.K.; Bhattacharyya, D. Structure-mechanics property relationship of waste derived biochars. Sci. Total Environ. 2015, 538, 611-620. [CrossRef] [PubMed] 
39. Maljaee, H.; Madadi, R.; Paiva, H.; Tarelho, L.; Ferreira, V.M. Incorporation of biochar in cementitious materials: A roadmap of biochar selection. Constr. Build. Mater. 2021, 283, 122757. [CrossRef]

40. Akinyemi, B.; Adesina, A. Recent advancements in the use of biochar for cementitious applications: A review. J. Build. Eng. 2020, 32, 101705. [CrossRef]

41. Lee, S.Y.; Sankaran, R.; Chew, K.W.; Tan, C.H.; Krishnamoorthy, R.; Chu, D.-T.; Show, P.-L. Waste to bioenergy: A review on the recent conversion technologies. BMC Energy 2019, 1, 4. [CrossRef]

42. Antar, M.; Lyu, D.; Nazari, M.; Shah, A.; Zhou, X.; Smith, D.L. Biomass for a sustainable bioeconomy: An overview of world biomass production and utilization. Renew. Sustain. Energy Rev. 2021, 139, 110691. [CrossRef]

43. Vigneshwaran, S.; Sundarakannan, R.; John, K.M.; Joel Johnson, R.D.; Prasath, K.A.; Ajith, S.; Arumugaprabu, V.; Uthayakumar, M. Recent advancement in the natural fiber polymer composites: A comprehensive review. J. Clean. Prod. 2020, 277, 124109. [CrossRef]

44. Cha, J.S.; Park, S.H.; Jung, S.-C.; Ryu, C.; Jeon, J.-K.; Shin, M.-C.; Park, Y.-K. Production and utilization of biochar: A review. J. Ind. Eng. Chem. 2016, 40,1-15. [CrossRef]

45. Tomczyk, A.; Sokołowska, Z.; Boguta, P. Biochar physicochemical properties: Pyrolysis temperature and feedstock kind effects. Rev. Environ. Sci. Biotechnol. 2020, 19, 191-215. [CrossRef]

46. Liu, N.; Charrua, A.B.; Weng, C.H.; Yuan, X.; Ding, F. Characterization of biochars derived from agriculture wastes and their adsorptive removal of atrazine from aqueous solution: A comparative study. Bioresour. Technol. 2015, 198, 55-62. [CrossRef] [PubMed]

47. Das, O.; Kim, N.K.; Hedenqvist, M.S.; Lin, R.J.T.; Sarmah, A.K.; Bhattacharyya, D. An Attempt to Find a Suitable Biomass for Biochar-Based Polypropylene Biocomposites. Environ. Manag. 2018, 62, 403-413. [CrossRef] [PubMed]

48. Giorcelli, M.; Khan, A.; Pugno, N.M.; Rosso, C.; Tagliaferro, A. Biomass and Bioenergy Biochar as a cheap and environmental friendly fi ller able to improve polymer mechanical properties. Biomass Bioenergy 2019, 120, 219-223. [CrossRef]

49. Tan, R.R. Data challenges in optimizing biochar-based carbon sequestration. Renew. Sustain. Energy Rev. 2019, 104, 174-177. [CrossRef]

50. Sizmur, T.; Quilliam, R.; Puga, A.P.; Moreno-Jiménez, E.; Beesley, L.; Gomez-Eyles, J.L. Application of Biochar for Soil Remediation. In Agricultural and Environmental Applications of Biochar: Advances and Barriers; Soil Science Society of America, Inc.: Madison, WI, USA, 2015; pp. 295-324.

51. Li, S.; Bi, X.; Tao, R.; Wang, Q.; Yao, Y.; Wu, F.; Zhang, C. Ultralong Cycle Life Achieved by a Natural Plant: Miscanthus $\times$ giganteus for Lithium Oxygen Batteries. ACS Appl. Mater. Interfaces 2017, 9, 4382-4390. [CrossRef] [PubMed]

52. Ronsse, F.; van Hecke, S.; Dickinson, D.; Prins, W. Production and characterization of slow pyrolysis biochar: Influence of feedstock type and pyrolysis conditions. GCB Bioenergy 2013, 5, 104-115. [CrossRef]

53. Zhao, S.X.; Ta, N.; Wang, X.D. Effect of Temperature on the Structural and Physicochemical Properties of Biochar with Apple Tree Branches as Feedstock Material. Energies 2017, 10, 1293. [CrossRef]

54. Das, O.; Kim, N.K.; Sarmah, A.K.; Bhattacharyya, D. Development of waste based biochar/wool hybrid biocomposites: Flammability characteristics and mechanical properties. J. Clean. Prod. 2017, 144, 79-89. [CrossRef]

55. Liu, Z.; Fei, B.; Jiang, Z.; Liu, X. Combustion characteristics of bamboo-biochars. Bioresour. Technol. 2014, 167, 94-99. [CrossRef]

56. Kumar, M.; Verma, B.B.; Gupta, R.C. Mechanical Properties of Acacia and Eucalyptus Wood Chars. Energy Source 1999, 21, 675-685. [CrossRef]

57. Zickler, G.A.; Schöberl, T.; Paris, O. Mechanical properties of pyrolysed wood: A nanoindentation study. Philos. Mag. 2006, 86, 1373-1386. [CrossRef]

58. Yang, X.; Wang, H.; Strong, P.; Xu, S.; Liu, S.; Lu, K.; Sheng, K.; Guo, J.; Che, L.; He, L.; et al. Thermal Properties of Biochars Derived from Waste Biomass Generated by Agricultural and Forestry Sectors. Energies 2017, 10, 469. [CrossRef]

59. Hankalin, V.; Ahonen, T.; Raiko, R. On Thermal Properties of a Pyrolysing Wood Particle. Process Eng. 2009, 16, 1-20.

60. Gupta, M.; Yang, J.; Roy, C. Specific heat and thermal conductivity of softwood bark and softwood char particles. Fuel 2003, 82, 919-927. [CrossRef]

61. Pyle, D.L.; Zaror, C.A. Heat transfer and kinetics in the low temperature pyrolysis of solids. Chem. Eng. Sci. 1984, 39, 147-158. [CrossRef]

62. Dupont, C.; Chiriac, R.; Gauthier, G.; Toche, F. Heat capacity measurements of various biomass types and pyrolysis residues. Fuel 2014, 115, 644-651. [CrossRef]

63. Jiang, X.; Li, B.; Li, J.; Guo, J. Study on the properties of different biochar to cement paste. In IOP Conference Series: Earth and Environmental Science; IOP Publishing: Bristol, UK, 2020; Volume 526. [CrossRef]

64. Li, V.C. On Engineered Cementitious Composites (ECC). J. Adv. Concr. Technol. 2003, 1, 215-230. [CrossRef]

65. Research and Markets, World Cement and Concrete Product Market Outlook 2020-2030. Available online: https: //www.globenewswire.com/en/news-release/2020/12/16/2146561/28124/en/World-Cement-and-Concrete-ProductMarket-Outlook-2020-2030-A-441-7-Billion-Global-Market-by-2023.html\#: \{\}:text=The\%20global\%20cement\%20and\%20 concrete \%20product\%20market\%20is\%20expected\%20to, the\%20measures\%20to\%20contain\%20it (accessed on 31 May 2021).

66. Akhtar, A.; Sarmah, A.K. Novel biochar-concrete composites: Manufacturing, characterization and evaluation of the mechanical properties. Sci. Total Environ. 2018, 616-617, 408-416. [CrossRef] [PubMed]

67. Imbabi, M.S.; Carrigan, C.; McKenna, S. Trends and developments in green cement and concrete technology. Int. J. Sustain. Built Environ. 2012, 1, 194-216. [CrossRef] 
68. Lu, L.H.; Pan, G.S.; Chen, S.L.; Zhang, Y. Strength of concrete with different contents of fly ash. J. Shenyang Univ. Technol. 2009, 31, 107-111.

69. Kriker, A.; Bali, A.; Debicki, G.; Bouziane, M.; Chabannet, M. Durability of date palm fibres and their use as reinforcement in hot dry climates. Cem. Concr. Compos. 2008, 30, 639-648. [CrossRef]

70. Gupta, S.; Kua, H.W.; Tan Cynthia, S.Y. Use of biochar-coated polypropylene fibers for carbon sequestration and physical improvement of mortar. Cem. Concr. Compos. 2017, 83, 171-187. [CrossRef]

71. Gupta, S.; Kua, H.W.; Pang, S.D. Biochar-mortar composite: Manufacturing, evaluation of physical properties and economic viability. Constr. Build. Mater. 2018, 167, 874-889. [CrossRef]

72. Ahmad, M.R.; Chen, B.; Duan, H. Improvement effect of pyrolyzed agro-food biochar on the properties of magnesium phosphate cement. Sci. Total Environ. 2020, 718, 137422. [CrossRef]

73. Wang, L.; Chen, L.; Tsang, D.C.W.; Kua, H.W.; Yang, J.; Ok, Y.S.; Ding, S.; Hou, D.; Poon, C.S. The roles of biochar as green admixture for sediment-based construction products. Cem. Concr. Compos. 2019, 104, 103348. [CrossRef]

74. Gupta, S.; Muthukrishnan, S.; Kua, H.W. Comparing influence of inert biochar and silica rich biochar on cement mortarHydration kinetics and durability under chloride and sulfate environment. Constr. Build. Mater. 2021, 268, 121142. [CrossRef]

75. Wang, L.; Chen, L.; Tsang, D.C.W.; Guo, B.; Yang, J.; Shen, Z.; Hou, D.; Ok, Y.S.; Poon, C.S. Biochar as green additives in cement-based composites with carbon dioxide curing. J. Clean. Prod. 2020, 258, 120678. [CrossRef]

76. Gupta, S.; Kua, H.W. Effect of water entrainment by pre-soaked biochar particles on strength and permeability of cement mortar. Constr. Build. Mater. 2018, 159, 107-125. [CrossRef]

77. Asadi Zeidabadi, Z.; Bakhtiari, S.; Abbaslou, H.; Ghanizadeh, A.R. Synthesis, characterization and evaluation of biochar from agricultural waste biomass for use in building materials. Constr. Build. Mater. 2018, 181, 301-308. [CrossRef]

78. Cuthbertson, D.; Berardi, U.; Briens, C.; Berruti, F. Biochar from residual biomass as a concrete filler for improved thermal and acoustic properties. Biomass Bioenergy 2019, 120, 77-83. [CrossRef]

79. Ahmad, S.; Khushnood, R.A.; Jagdale, P.; Tulliani, J.M.; Ferro, G.A. High performance self-consolidating cementitious composites by using micro carbonized bamboo particles. Mater. Des. 2015, 76, 223-229. [CrossRef]

80. Mrad, R.; Chehab, G. Mechanical and microstructure properties of biochar-based mortar: An internal curing agent for PCC. Sustainability 2019, 11, 2491. [CrossRef]

81. Sirico, A.; Bernardi, P.; Belletti, B.; Malcevschi, A.; Dalcanale, E.; Domenichelli, I.; Fornoni, P.; Moretti, E. Mechanical characterization of cement-based materials containing biochar from gasification. Constr. Build. Mater. 2020, 246, 118490. [CrossRef]

82. Dixit, A.; Verma, A.; Pang, S.D. Dual waste utilization in ultra-high performance concrete using biochar and marine clay. Cem. Concr. Compos. 2021, 120, 104049. [CrossRef]

83. Mo, L.; Fang, J.; Huang, B.; Wang, A.; Deng, M. Combined effects of biochar and MgO expansive additive on the autogenous shrinkage, internal relative humidity and compressive strength of cement pastes. Constr. Build. Mater. 2019, 229, 116877. [CrossRef]

84. Navaratnam, S.; Wijaya, H.; Rajeev, P.; Mendis, P.; Nguyen, K. Residual stress-strain relationship for the biochar-based mortar after exposure to elevated temperature. Case Stud. Constr. Mater. 2021, 14, e00540. [CrossRef]

85. Chin, C.O.; Yang, X.; Kong, S.Y.; Paul, S.C.; Susilawati; Wong, L.S. Mechanical and thermal properties of lightweight concrete incorporated with activated carbon as coarse aggregate. J. Build. Eng. 2020, 31, 101347. [CrossRef]

86. Wu, F.; Liu, C.; Zhang, L.; Lu, Y.; Ma, Y. Comparative study of carbonized peach shell and carbonized apricot shell to improve the performance of lightweight concrete. Constr. Build. Mater. 2018, 188, 758-771. [CrossRef]

87. Praneeth, S.; Saavedra, L.; Zeng, M.; Dubey, B.K.; Sarmah, A.K. Biochar admixtured lightweight, porous and tougher cement mortars: Mechanical, durability and micro computed tomography analysis. Sci. Total Environ. 2021, 750, 142327. [CrossRef] [PubMed]

88. Muthukrishnan, S.; Gupta, S.; Kua, H.W. Application of rice husk biochar and thermally treated low silica rice husk ash to improve physical properties of cement mortar. Theor. Appl. Fract. Mech. 2019, 104, 102376. [CrossRef]

89. Gupta, S.; Kua, H.W.; Koh, H.J. Application of biochar from food and wood waste as green admixture for cement mortar. Sci. Total Environ. 2018, 619-620, 419-435. [CrossRef] [PubMed]

90. Gupta, S.; Kua, H.W. Carbonaceous micro-filler for cement: Effect of particle size and dosage of biochar on fresh and hardened properties of cement mortar. Sci. Total Environ. 2019, 662, 952-962. [CrossRef]

91. Nisticò, R.; Lavagna, L.; Versaci, D.; Ivanchenko, P.; Benzi, P. Chitosan and its char as fillers in cement-base composites: A case study. Bol. Soc. Esp. Ceram. Vidr. 2020, 59, 186-192. [CrossRef]

92. Praneeth, S.; Guo, R.; Wang, T.; Dubey, B.K.; Sarmah, A.K. Accelerated carbonation of biochar reinforced cement-fly ash composites: Enhancing and sequestering CO2 in building materials. Constr. Build. Mater. 2020, 244, 118363. [CrossRef]

93. Cosentino, I.; Restuccia, L.; Ferro, G.A.; Tulliani, J.M. Type of materials, pyrolysis conditions, carbon content and size dimensions: The parameters that influence the mechanical properties of biochar cement-based composites. Theor. Appl. Fract. Mech. 2019, 103, 102261. [CrossRef]

94. Restuccia, L.; Ferro, G.A. Promising low cost carbon-based materials to improve strength and toughness in cement composites. Constr. Build. Mater. 2016, 126, 1034-1043. [CrossRef]

95. Restuccia, L.; Ferro, G.A. Influence of filler size on the mechanical properties of cement-based composites. Fatigue Fract. Eng. Mater. Struct. 2018, 41, 797-805. [CrossRef]

96. Lian, C.; Zhuge, Y.; Beecham, S. The relationship between porosity and strength for porous concrete. Constr. Build. Mater. 2011, 25, 4294-4298. [CrossRef] 
97. Schiller, K.K. Strength of porous materials. Cem. Concr. Res. 1971, 1, 419-422. [CrossRef]

98. Restuccia, L.; Ferro, G.A. Nanoparticles from food waste: A "green" future for traditional building materials. In Proceedings of the 9th International Conference on Fracture Mechanics of Concrete and Concrete Structures, Berkeley, CA, USA, 22-25 May 2016.

99. Ferro, G.A.; Ahmad, S.; Khushnood, R.A.; Restuccia, L.; Tulliani, J.M. Improvements in self-consolidating cementitious composites by using micro carbonized aggregates. Frat. Integrita Strutt. 2014, 30, 75-83. [CrossRef]

100. Falliano, D.; De Domenico, D.; Sciarrone, A.; Ricciardi, G.; Restuccia, L.; Ferro, G.; Tulliani, J.M.; Gugliandolo, E. Influence of biochar additions on the fracture behavior of foamed concrete. Frat. Integrita Strutt. 2020, 14, 189-198. [CrossRef]

101. Ahmad, S.; Tulliani, J.M.; Ferro, G.A.; Khushnood, R.A.; Restuccia, L.; Jagdale, P. Crack path and fracture surface modifications in cement composites. Frat. Integrita Strutt. 2015, 9, 34. [CrossRef]

102. Filho, J.D.A.M.; Silva, F.D.A.; Toledo Filho, R.D. Degradation kinetics and aging mechanisms on sisal fiber cement composite systems. Cem. Concr. Compos. 2013, 40, 30-39. [CrossRef]

103. Pan, Z.; He, L.; Qiu, L.; Korayem, A.H.; Li, G.; Zhu, J.W.; Collins, F.; Li, D.; Duan, W.H.; Wang, M.C. Mechanical properties and microstructure of a graphene oxide-cement composite. Cem. Concr. Compos. 2015, 58, 140-147. [CrossRef]

104. Rossi, P.; Arca, A.; Parant, E.; Fakhri, P. Bending and compressive behaviours of a new cement composite. Cem. Concr. Res. 2005, 35, 27-33. [CrossRef]

105. Laukaitis, A.; Žurauskas, R.; Keriene, J. The effect of foam polystyrene granules on cement composite properties. Cem. Concr. Compos. 2005, 27, 41-47. [CrossRef]

106. Shih, J.Y.; Chang, T.P.; Hsiao, T.C. Effect of nanosilica on characterization of Portland cement composite. Mater. Sci. Eng. A 2006, 424, 266-274. [CrossRef]

107. Li, Z.; Wang, H.; He, S.; Lu, Y.; Wang, M. Investigations on the preparation and mechanical properties of the nano-alumina reinforced cement composite. Mater. Lett. 2006, 60, 356-359. [CrossRef]

108. De Silva, F.A.; Filho, R.D.T.; de Filho, J.A.M.; de Fairbairn, E.M.R. Physical and mechanical properties of durable sisal fiber-cement composites. Constr. Build. Mater. 2010, 24,777-785. [CrossRef]

109. Qin, Y.; Pang, X.; Tan, K.; Bao, T. Evaluation of pervious concrete performance with pulverized biochar as cement replacement. Cem. Concr. Compos. 2021, 119, 104022. [CrossRef]

110. Gupta, S.; Kua, H.W.; Pang, S.D. Effect of biochar on mechanical and permeability properties of concrete exposed to elevated temperature. Constr. Build. Mater. 2020, 234, 117338. [CrossRef]

111. Akhtar, A.; Sarmah, A.K. Strength improvement of recycled aggregate concrete through silicon rich char derived from organic waste. J. Clean. Prod. 2018, 196, 411-423. [CrossRef]

112. Serrano, R.; Cobo, A.; Prieto, M.I.; de las González, M.N. Analysis of fire resistance of concrete with polypropylene or steel fibers. Constr. Build. Mater. 2016, 122, 302-309. [CrossRef]

113. Rostami, V.; Shao, Y.; Boyd, A.J.; He, Z. Microstructure of cement paste subject to early carbonation curing. Cem. Concr. Res. 2012, 42, 186-193. [CrossRef]

114. Gupta, S.; Kua, H.W.; Pang, S.D. Biochar-concrete composite: Manufacturing, characterization and performance evaluation at elevated temperature. Acad. J. Civ. Eng. 2019, 37, 507-513. [CrossRef]

115. Cuthbertson, D. The Production of Pyrolytic Biochar for Addition in Value-Added Composite Material. Master's Thesis, The University of Western Ontario, London, ON, Canada, 2018.

116. Yang, S.; Wi, S.; Lee, J.; Lee, H.; Kim, S. Biochar-red clay composites for energy efficiency as eco-friendly building materials: Thermal and mechanical performance. J. Hazard. Mater. 2019, 373, 844-855. [CrossRef]

117. Lee, H.; Yang, S.; Wi, S.; Kim, S. Thermal transfer behavior of biochar-natural inorganic clay composite for building envelope insulation. Constr. Build. Mater. 2019, 223, 668-678. [CrossRef]

118. Tan, K.; Pang, X.; Qin, Y.; Wang, J. Properties of cement mortar containing pulverized biochar pyrolyzed at different temperatures. Constr. Build. Mater. 2020, 263, 120616. [CrossRef]

119. Shanmugam, V.; Mensah, R.A.; Försth, M.; Sas, G.; Restás, Á.; Addy, C.; Xu, Q.; Jiang, L.; Neisiany, R.E.; Singha, S.; et al. Circular economy in biocomposite development: State-of-the-art, challenges and emerging trends. Compos. Part C Open Access 2021, 5, 100138. [CrossRef]

120. Matuštík, J.; Hnátková, T.; Kočí, V. Life cycle assessment of biochar-to-soil systems: A review. J. Clean. Prod. 2020, 259, 120998. [CrossRef]

121. Guinée, J.B.; Heijungs, R.; Huppes, G.; Zamagni, A.; Masoni, P.; Buonamici, R.; Ekvall, T.; Rydberg, T. Life Cycle Assessment: Past, Present, and Future †. Environ. Sci. Technol. 2011, 45, 90-96. [CrossRef] [PubMed]

122. Campos, J.; Fajilan, S.; Lualhati, J.; Mandap, N.; Clemente, S. Life Cycle Assessment of Biochar as a Partial Replacement to Portland Cement. In IOP Conference Series: Earth and Environmental Science; IOP Publishing: Bristol, UK, 2020; Volume 479, p. 012025. [CrossRef]

123. Gupta, S.; Kashani, A. Utilization of biochar from unwashed peanut shell in cementitious building materials-Effect on early age properties and environmental benefits. Fuel Process. Technol. 2021, 218, 106841. [CrossRef]

124. Di Tommaso, M.; Bordonzotti, I. NOx Adsorption, Fire Resistance and $\mathrm{CO}_{2}$ Sequestration of High Performance, High Durability Concrete Containing Activated carbon. In Proceedings of the Ii International Conference on Concrete Sustainability-Iccs16, Madrid, Spain, 13-15 June 2016; pp. 1036-1047. 
125. Suarez, D. Biochar as Eco-Friendly Filler to Enhance the Sustainable Performance Cement. Master's Thesis, Politecnico di Torino, Torino, Italy, 2018.

126. Horgnies, M.; Dubois-Brugger, I.; Gartner, E.M. NOx de-pollution by hardened concrete and the influence of activated charcoal additions. Cem. Concr. Res. 2012, 42, 1348-1355. [CrossRef]

127. Krou, N.J.; Batonneau-Gener, I.; Belin, T.; Mignard, S.; Horgnies, M.; Dubois-Brugger, I. Mechanisms of NOx entrapment into hydrated cement paste containing activated carbon-Influences of the temperature and carbonation. Cem. Concr. Res. 2013, 53, 51-58. [CrossRef]

128. Krou, N.J.; Batonneau-Gener, I.; Belin, T.; Mignard, S.; Javierre, I.; Dubois-Brugger, I.; Horgnies, M. Reactivity of volatile organic compounds with hydrated cement paste containing activated carbon. Build. Environ. 2015, 87, 102-107. [CrossRef]

129. Huang, Y.; Anderson, M.; McIlveen-Wright, D.; Lyons, G.A.; McRoberts, W.C.; Wang, Y.D.; Roskilly, A.P.; Hewitt, N.J. Biochar and renewable energy generation from poultry litter waste: A technical and economic analysis based on computational simulations. Appl. Energy 2015, 160, 656-663. [CrossRef]

130. Shackley, S.; Hammond, J.; Gaunt, J.; Ibarrola, R. The feasibility and costs of biochar deployment in the UK. Carbon Manag. 2011, 2, 335-356. [CrossRef]

131. Drzymała, T.; Jackiewicz-Rek, W.; Gałaj, J.; Šukys, R. Assessment of mechanical properties of high strength concrete (HSC) after exposure to high temperature. J. Civil. Eng. Manag. 2018, 24, 138-144. [CrossRef]

132. Rudnik, E.; Drzymała, T. Thermal behavior of polypropylene fiber-reinforced concrete at elevated temperatures. J. Therm. Anal. Calorim. 2018, 131, 1005-1015. [CrossRef]

133. Jackiewicz-Rek, W.; Drzymała, T.; Kuś, A.; Tomaszewski, M. Durability of high performance concrete (HPC) subject to fire temperature impact. Arch. Civil. Eng. 2016, 62, 73-93. [CrossRef]

134. Shanmugam, V.; Das, O.; Babu, K.; Marimuthu, U.; Veerasimman, A.; Johnson, D.J.; Neisiany, R.E.; Hedenqvist, M.S.; Ramakrishna, S.; Berto, F. Fatigue behaviour of FDM-3D printed polymers, polymeric composites and architected cellular materials. Int. J. Fatigue 2021, 143, 106007. [CrossRef]

135. Das, O.; Loho, T.A.; Capezza, A.J.; Lemrhari, I.; Hedenqvist, M.S. A novel way of adhering PET onto protein (wheat gluten) plastics to impart water resistance. Coatings 2018, 8, 388. [CrossRef]

136. Babu, K.; Das, O.; Shanmugam, V.; Mensah, R.A.; Försth, M.; Sas, G.; Restás, Á.; Berto, F. Fire Behavior of 3D-Printed Polymeric Composites. J. Mater. Eng. Perform. 2021, 30, 4745-4755. [CrossRef] 